\title{
THE DETERMINANTS AND CONSEQUENCES \\ OF FINANCIAL EDUCATION IN THE \\ WORKPLACE: EVIDENCE FROM A SURVEY \\ OF HOUSEHOLDS
}

\author{
B. Douglas Bernheim \\ Daniel M. Garrett
}

NBER Working Paper 5667

\author{
NATIONAL BUREAU OF ECONOMIC RESEARCH \\ 1050 Massachusetts Avenue \\ Cambridge, MA 02138 \\ July 1996
}

We are grateful to the National Science Foundation (Grant Number SBR94-09043 and Grant Number SBR95-11321) for financial support. Seminar participants at New York University, Columbia University, and the National Bureau of Economic Research provided helpful comments. We would also like to thank Merrill Lynch, Inc. for collecting the data required to conduct this study. This paper is part of NBER's research programs in Aging and Public Economics. Any opinions expressed are those of the authors and not those of the National Bureau of Economic Research.

(C) 1996 by B. Douglas Bernheim and Daniel M. Garrett. All rights reserved. Short sections of text, not to exceed two paragraphs, may be quoted without explicit permission provided that full credit, including $(\mathcal{C}$ notice, is given to the source. 


\title{
THE DETERMINANTS AND CONSEQUENCES \\ OF FINANCIAL EDUCATION IN THE \\ WORKPLACE: EVIDENCE FROM A SURVEY \\ OF HOUSEHOLDS
}

\begin{abstract}
In recent years, the United States has witnessed significant growth in programs of financial and retirement education in the workplace. This phenomenon provides an opportunity to assess the effects of targeted education programs on financial choices. This paper uses a novel household survey to develop econometric evidence on the efficacy of employer-based financial education. While our primary focus concerns the effects of these programs on saving (both in general and for the purposes of retirement), we also examine a number of collateral issues. These include the circumstances under which employers offer, and employees participate in, financial education programs, and the effects of these programs on sources of information and advice concerning retirement planning. Our findings indicate that employer-based retirement education strongly influences household financial behavior.
\end{abstract}

B. Douglas Bernheim

Department of Economics

Stanford University

Stanford, CA 94305-6072

and NBER
Daniel M. Garrett

Department of Economics

Stanford University

Stanford, CA 94305-6072 


\section{Introduction}

In recent years, low rates of saving among U.S. households have attracted considerable attention. Most of the related public policy debate has focused on the efficacy of tax incentives for saving. From the available evidence, it is not at all clear that tax policy -- by itself -- adequately addresses the underlying causes of low saving (see Bernheim, 1996, for a review of the literature). Some recent research departs from traditional life-cycle assumptions by investigating the possibility that low saving results in part from "financial illiteracy." For example, Bernheim (1994a, 1995a) argues that many individuals poorly understand their economic vulnerabilities, as well as the economic incentives that some tax provisions seek to create. If so, then education policy may prove to be a powerful tool, either in isolation or in combination with tax incentives, for stimulating rates of saving. This possibility has recently led the Department of Labor to launch "a national pension education program aimed at drawing the attention of American workers to the importance of taking personal responsibility for their retirement security" (Berg, 1995, p. 2).

Unfortunately, there is virtually no hard evidence concerning the effects of education on financial decisions. Although anecdotal evidence suggests that the post-War increase in saving by Japanese households may be at least partially attributable to an extensive educational and promotional campaign, there are other competing explanations for the same phenomenon (see Bernheim, 1991, or Central Council for Savings Promotion, 1981). Likewise, correlations between an individual's general level of educational attainment and his or her rate of saving (documented by Bernheim and Scholz, 1993, and by Hubbard, Skinner, and Zeldes, 1995) may be attributable to other related factors, such as rates of time preference.

The rapid growth of financial and retirement education in the workplace provides useful opportunities to study the effects of education on financial decisions. As of $1994,88 \%$ of large employers offered some form of financial education, and more than two-thirds had added these programs after $1990{ }^{1}$ While this phenomenon is often linked to the increasing popularity of employee-directed pension plans, such

\footnotetext{
1 "Employees getting more: Investment education, planning help on the increase," Pensions \& Investments,
} January 23,1995 , p. 74 
as 401(k)s (see e.g. Employee Benefit Research Institute, 1995), educational programs are also becoming increasingly common among firms that sponsor only defined benefit plans (see section 3 , below).

Employer-based financial education takes many forms, including written materials (brochures, plan descriptions, fund prospectuses, newsletters, and memos), one-on-one counseling or financial planning, seminars, workshops, focus groups, interactive voice response systems, 800 numbers, videos, and interactive software. Topics covered often include basic investment terminology, asset allocation principles, the concepts of risk tolerance and risk-return tradeoffs, the effects of inflation, the estimation of retirement income needs and retirement income sources, retirement strategies, and the impact of preretirement withdrawals on retirement income. While cmphasis varies, nearly all programs cover asset allocation, and sizable majorities cover retirement income needs (73\%) and retirement strategies $(88 \%)^{2}$. Thus, one might well expect educational measures to affect a wide range of behaviors, including plan participation, voluntary contributions, portfolio mix, and the individual's overall rate of saving.

Existing evidence on the effects of retirement education in the workplace is confined to qualitative surveys and case studies. According to the Employec Benefit Research Institute (1994), 92\% of $40 \mathrm{l}(\mathrm{k})$ participants say that they read materials provided by their employers; of those, $44 \%$ say that they allocate their funds differently, and $33 \%$ say that they contribute more to their plans. Unfortunately, there is no way to verify the accuracy of these responses, and in any case the survey did not attempt to measure the magnitude of the behavioral effects. Employers who enhanced their educational efforts also tend to report increases in participation (A. Foster Higgins \& Co., Inc., 1994), but the available evidence does not establish whether these increases are out of the ordinary. Case studies frequently cite dramatic changes in behavior (see e.g. Employee Benefit Research Institute, 1995, or Borleis and Wedell, 1994), but the link to education is usually speculative, and often confounded by other factors. For example, one company views its communications program as the "most important factor" bchind its $92 \% 40 \mathrm{l}(\mathrm{k})$ participation rate; yet it also matches $100 \%$ of employee contributions up to the first $3 \%$ of compensation (Geisel, 1995)

\footnotetext{
${ }^{2}$ See Employee Benefit Research Institute (1995, p. 15)
} 
The object of this paper is to provide the first econometric evidence on the efficacy of employerbased retirement education. We make use of a novel survey of U.S. households. Bayer, Bernheim, and Scholz (1996) address similar questions using data obtained from employers. Both data sources have advantages and disadvantages. While the employer data is probably more reliable, it does not contain information on assets held outside of retirement plans. Thus, household data is required to determine the extent to which educationally-induced changes in retirement portfolios are offset by other changes in behavior. In section 2, we describe the survey, discuss its limitations, and explore the reliability of the data.

Section 3 provides an analysis of the circumstances under which employers offer, and employees participate in, retirement education programs. These issues are important for the analysis that follows since the existence of educational programs, as well as the decision to participate in these programs, may be correlated with the characteristics of employees. ${ }^{3}$ Our evidence is consistent with the hypothesis that educational programs are typically remedial, in the sense that they tend to be offered more frequently in situations where employees are predisposed against saving. Moreover, there does not appear to be a positive relation between the decision to participate in educational programs and characteristics that correlate with the predisposition to save. We find that employers are more likely to offer education in the context of selfdirected plans, but a surprising amount of education is also offered in the context of more traditional plans Employees are far more likely to make use of educational offerings, however, when the plan is self-directed.

We also provide an analysis of the effects of employer-based education on sources of information and advice concerning retirement planning (section 4). This issue is important, since education is not likely to have a significant effect on behavior if it simply displaces other similar sources of guidance (such as financial planners). We find that employees do rely on employer-based education to a large extent when it is available. While education tends primarily to displace sources of questionable reliability (c.g. parents and friends), it

\footnotetext{
${ }^{3} \mathrm{~A}$ similar issue arises in the context of the literature that attempts to assess the impact of $401(\mathrm{k}) \mathrm{s}$ on saving. As several commentators have observed, employers may offer $40 \mathrm{l}(\mathrm{k}) \mathrm{s}$ in response to the demands of employees who are interested in saving, or alternatively employees who are predisposed to save may seek out employers with $401(\mathrm{k})$ plans (see e.g. Bernheim, 1994b, or Engen, Gale, and Scholz, 1994)
} 
also replaces potentially authoritative sources (e.g. financial planners) to a significant extent.

We find that rates of saving, both in general and for the purposes of retirement, increase significantly with the provision of retirement education (section 5). Saving for all purposes actually increases by a larger amount than saving for retirement. We also find that education significantly stimulates participation in and contributions to $401(\mathrm{k})$ plans (section 6). These results are particularly striking in light of the fact (discussed above) that employers tend to offer education in circumstances where employees are less predisposed towards saving. Due to data limitations, we are unable to study the effects of education on portfolio allocation.

\section{The Data}

Unfortunately, none of the standard sources of information on household finances (such the Survey of Consumer Finances, and the Survey of Income and Program Participation, the Panel Study on Income Dynamics) contain information on employer-based retirement education. To address the nexus of issues discussed in section $\mathrm{I}$, it was necessary to collect new data.

The first author of this paper has directed an ongoing project, sponsored by Merrill Lynch, Inc., to monitor the adequacy of personal saving through annual household surveys (see Bernheim, 1995b). For the Fall of 1994, the survey instrument was expanded to cover a number of new topics, including employer-based financial education. ${ }^{4}$ Data were collected during the month of November from a nationally representative sample of respondents between the ages of 30 and 48 . A total of 2,055 surveys were completed. ${ }^{5}$

The survey gathered standard economic and demographic information, including household assets and liabilities, rates of saving, earnings, income, pension coverage, employment status, gender, marital status, age, ethnic group, education, and household composition. It also covered less standard topics, such as retirement education in the workplace, economic and financial knowledge, sources of information and advice on retirement planning, and childhood experiences of potential relevance to later financial decisions.

\footnotetext{
${ }^{4}$ The survey was designed in cooperation with the first author of this paper, and fielded for Merrill Lynch by the Luntz Research Companies.

${ }^{5}$ Respondents who terminated their interviews before completion of the survey are not included in this sample.
} 
One potential concern is that the survey was administered by telephone. While telephone interviews are usually regarded as less reliable than face-to-face interviews, the survey was designed to achieve a high level of compliance and to assure accuracy. Questions were sequenced according to their degree of invasiveness. This permitted interviewers to establish credibility, to place respondents at ease, and to engage them in dialogue. Interviewers first asked respondents to assess their own levels of financial knowledge, and then moved on to childhood experiences (whether the respondent received an allowance, held a regular job, and so forth), sources of information and advice about retirement (including financial education in the workplace), and questions designed to test economic and financial knowledge. Invasive questions concerning assets and earnings were deferred until later in the survey, and the most innocuous of these (for example, the household's rate of saving) were placed before the most problematic ones (primarily those designed to elicit asset holdings). As a result, rates of refusal were surprisingly low: $79.1 \%$ of completed surveys contained quantitative answers to all questions conceming components of wealth, and $90.4 \%$ contained quantitative answers to all questions concerning earnings. While high response rates are encouraging, it is important to judge the reliability of the data by making appropriate comparisons with known benchmarks (see below).

Table I lists variable names and abbreviated definitions. It also identifies each variable as binary (a dummy), continuous (defined over an open range), or categorical (defined over a discrete set of values).

The survey contains two questions concerning employer-based retirement education. The first asks whether the respondent's employer offers seminars, professional assistance, or informative materials to assist with retirement planning. Answers to this question are summarized by the variable OEBRE, which is set equal to unity when assistance is available, and zero otherwise. Nearly all respondents $(2,037$ out of 2,055$)$ provided valid answers to this question (other than "don't know" or "refused"), with approximately half indicating that some form of retirement education is available. The second question asks whether the respondent has taken advantage of these offerings. This question forms the basis for the variable UEBRE.

Obviously, OEBRE and UEBRE are coarse measures of exposure to employer-based retirement education. Unfortunately, detailed descriptions of program structure and content are not available. One 
should therefore view this study as an investigation of the average effects of educational activities -- our analysis almost certainly understates the effects of the best programs. We expect to refine our treatment of education in subsequent work using more detailed data sources. ${ }^{6}$.

Several variables listed in table I measure aspects of pension coverage. RE40lK indicates whether the respondent was eligible to participate in "a $401(\mathrm{k})$ or some other tax-deferred salary reduction plan" sponsored by his or her employer; RP40IK indicates whether the respondent actively participated in this plan.. SE40IK and SP40IK summarize similar information for spouses. RB401K and SB40IK (for respondents and spouses, respectively) measure accumulated balances in tax-deferred salary reduction plans sponsored by past or present employers.? ROPEN and SOPEN indicate whether the respondent (or spouse) participates in any other retirement plan sponsored by his or her employer.

Table $\mathrm{l}$ also lists a number of demographic variables, the definitions of which are generally selfexplanatory. RED (SED) measures the respondent's (spouse's) highest level of educational attainment on a scale of 1 (no high school degree) to 6 (some post-graduate education in addition to a college degree).

Information on employment includes earnings and work status. Measured earnings reflects only what respondents (spouses) made at their jobs or through self-employment (before taxes). LREARN (LSEARN) is constructed by adding one dollar to the respondent's (spouse's) reported earnings, and taking the natural logarithm. ${ }^{8}$ Respondents were also asked to describe themselves (and their spouses) as a student, housewife, unemployed, employed full-time by a company other than their own, employed part-time by a company other than their own, self-employed full-time, or self-employed part-time. Answers to these questions are used to construct RSE, SSE, RPART, SPART, RNOWORK, and SNOWORK. For our purposes, students,

\footnotetext{
${ }^{6}$ More detailed information on educational programs are contained in surveys of employers fielded by Hewitt Associates and KPMG Peat Marwick.

${ }^{7}$ It is worth emphasizing that these variables reflect eligibility and participation not only for $401(\mathrm{k}) \mathrm{s}$, but also for other kinds of plans, such as 403(b)s. We use the 401(k) label for notational brevity.

${ }^{8}$ The addition of one dollar is necessary prior to taking the natural logarithm because some respondents reports earnings of zero.
} 
housewives, and the unemployed are categorized as "not employed."

The data also contain measures of wealth and saving. Questions on homes, businesses, other real property, financial assets (including cash, bank accounts, retirement accounts, and other investments such as stocks, bonds, and mutual funds), and debt are used to construct an all-inclusive measure of net worth, TW In some specifications, we also use a transformation of this variable, LOGTW, which is constructed by rescaling TW so that its minimum value is one dollar, and applying natural logarithms. RW measures the total amount of money that respondents report having saved specifically for retirement. Finally, the survey collected self-assessed rates of saving. The variables TSAVE and RSAVE measure, respectively, respondents' estimates of the percentage of yearly houschold earnings (not including income earned on assets and investments) saved in all forms, and the percentage of earnings saved for retirement. The reliability of self-reported measures of saving is open to question; we return to this issue in section 5.

Table 1 lists two additional variables under the heading "other." In subsequent sections, these are generally used as proxies for underlying preferences. PARSAVE provides a measure of parental attitudes towards saving (scaled from one to five), based on the respondents' assessments of whether their parents saved a lot less, somewhat less, the same, somewhat more, or a lot more than other families. TSCORE measures economic and financial knowledge, based on a series of factual and conceptual questions. ${ }^{9}$ For each of these questions, we assigned a "relative knowledge score," defined as the fraction of the population who gave answers that were at least as far in absolute value as the respondent's answer from the true answer ${ }^{10}$ This procedure normalizes the scores for each question to reflect difficulty, so that no question (or group of questions) dominates the variation in total scores. For questions that require continuous, quantitative

${ }^{9}$ Factual questions concerned rates of unemployment, inflation, taxation (in the lowest federal income tax bracket), and interest (on 30 year mortgages), and levels of the minimum wage, the federal deficit, federal debt per household, and Dow Jones average. Conceptual questions probed the respondent's understanding of real vs. nominal investment returns and risk-return tradeoffs.

${ }^{10}$ Suppose, for example, that we ask four individuals (A, B, C, and D) the same question. Suppose that the true answer is " 5 ," that $A$ answers " 6 ," $B$ and $C$ answer " 8 ," and $D$ answers " 0 ." Then A would receive a score of $100, B$ and $\mathrm{C}$ would receive scores of 75 , and $\mathrm{C}$ would receive a score of 25 . 
responses, relative knowledge scores are also less arbitrary than coding answers as "right" or "wrong." TSCORE is defined as the average relative knowledge score over the respondent's answers.

Since the reliability of telephone interviews is open to dispute, we have undertaken comparisons between the Merrill Lynch survey and other recognized data sources. Suitable benchmarks must mimic the survey's focus on members of the baby boom generation. One convenient source of information on this group is a study by the Congressional Budget Office (1993) (henceforth, CBO), which uses the 1989 Survey of Consumer Finances and the 1990 Current Population Survey. The CBO tabulates statistics for two age groups: $25-34$, and 35-44. For the older group, one can make comparisons with an analogous sample drawn from the Merrill Lynch survey. Since the CBO's data were collected four to five years earlier, discrepancies are to be expected. However, given the slow rate of real wage growth over this period, it is natural to expect a rough correspondence belween the surveys. Thus, the $\mathrm{CBO}$ study provides a meaningful benchmark.

The data contained in the first section of table 2, labeled "general characteristics," indicates that the composition of the Merrill Lynch sample differs systematically from the comparison sample in several respects. The most important distinction is that home ownership is much more common in the Merrill Lynch sample ( $81.1 \%$ vs. $65.2 \%)$. Apparently, the chances of contacting a prospective respondent via telephone are higher for homeowners than for renters. Respondents in the Merrill Lynch sample are more likely to be married $(73.8 \%$ vs. $62.0 \%)$, and are somewhat better educated than those in the comparison sample.

The second section of table 2 contains information on household income. Comparability is imperfect, since the benchmark statistics refer to total houschold income, while the Merrill Lynch survey responses measure total earnings from employment. However, for the age group in question, employment is the predominant source of household income. With this qualification in mind, there is a striking correspondence between median household income for the Merrill Lynch and benchmark samples. The overall median is only slightly higher in the Merrill Lynch sample $(\$ 48,000$ vs. $\$ 46,359)$. There is astonishing little difference across the two samples in median incomes for unmarried individuals, all married couples, single-earner married couples, and dual-earner married couples. The numbers match up only slightly 
less well when the samples are segmented by educational attainment.

The third and fourth sections of table 2 presents similar comparisons for total household wealth and non-housing wealth. Reported levels of wealth are generally higher in the Merrill Lynch sample than in the comparison sample. For example, the median for all households is $\$ 95,000$ in the Merrill Lynch sample, versus $\$ 65,433$ in the comparison sample. Despite this discrepancy, the variation in median wealth across subgroups (defined by marital status and educational attainment) is qualitatively similar for the two samples.

The apparent discrepancies in median wealth are easily explained. As indicated in table 2, the CBO found an enormous disparity between median wealth for homeowners $(\$ 111,068)$ and non-homeowners $(\$ 1,811)$. When the data is segmented in this way, the Merrill Lynch survey matches the benchmarks much more closely ( $\$ 126,000$ for homeowners, $\$ 4,000$ for non-homeowners). Thus, the oversampling of homeowners, noted above, leads to the selection of a wealthier sample. One can compensate for this selectivity by re-weighting the Merrill Lynch sample to produce the same proportion of home ownership as in the comparison sample (see the final column of table 2). While this results in estimates of median income that are slightly lower than the CBO's numbers, part of the difference is probably attributable to the omission of capital income and transfers. Re-weighting reduces median wealth more dramatically than median income (for example, median wealth for all households falls to $\$ 61,000$, versus $\$ 65,433$ for the comparison sample). Given the large variances associated with measures of wealth, the re-weighted figures are remarkably close to the benchmarks (both for total wealth and for non-housing wealth). The largest discrepancy -- net worth for college educated household heads -- is consistent with the corresponding discrepancy for household income.

The final section of table 2 contains information on pensions. Since the CBO does not report this information, and since we were unable to identify another appropriate published benchmark, we constructed our own comparison sample using the 1992 Survey of Consumer Finances (SCF). We selected a subsample to mirror the entire Merrill Lynch sample, rather than a restricted age group. Since the SCF did not gather information on eligibility separately for different types of pensions, we restricted our attention to overall rates of pension coverage. The fractions of married women, single women, and married men with access to 
pension plans are very similar across the two samples. Results for single men are anomalous. This discrepancy is probably not a significant indictment of data quality since single men comprise the smallest of the subsamples. Table 2 also indicates that median reported balances in $401(k)$ accounts for the SCF are very close to median balances in the somewhat broader category of accounts for the Merrill Lynch survey.

In summary, comparisons between the Merrill Lynch survey and recognized benchmarks reveal that the survey probably oversampled certain population subgroups, most notably homeowners. However, once one accounts for this phenomenon, medians for income and wealth correspond remarkably closely to statistics obtained from other sources. Rates of pension coverage are also similar. These findings provide us with considerable comfort concerning the accuracy of the Merrill Lynch data.

\section{The Determinants of Employer-Based Financial Education}

The rapid growth of financial education in the workplace is an intriguing phenomenon. A reading of the trade press suggests four possible explanations. First, rules governing employer liability in the context of self-directed pension plans (particularly $40 \mathrm{l}(\mathrm{k}) \mathrm{s})$ may stimulate educational initiatives. Section 404(c) of ERISA, which spells out conditions under which an employer is relieved of liability for investment results when sponsoring a "participant-controlled" plan, creates an affirmative obligation to provide adequate disclosure for informed investment decisions." Second, employers may adopt educational programs when they run afoul of the non-discrimination requirements that preclude the existence of large discrepancies between contribution rates for highly compensated and non-highly compensated employees. By encouraging participation among non-highly compensated employees, education may relax binding constraints on highly compensated employees (see Garrett, 1995, for further discussion of non-discrimination requirements and

\footnotetext{
${ }^{11}$ This first explanation is probably of limited importance. The disclosure requirement is modest, and does not necessitate activities that are recognizable as meaningful financial education. Indeed, the fact that section $404(\mathrm{c})$ does not specifically mention broader financial education has led some observers to fear that the provision of education -beyond simple disclosure -- would create a potential fiduciary liability. The Department of Labor has recently attempted to alter this perception by drafting an "interpretive bulletin" which is "intended to enable employers, plan officials and educational providers to distinguish participant education from fiduciary activities and, thereby, encourage these individuals to institute participant education programs without fear of inadvertently incurring potential fiduciary liability" (Berg, 1995, p. 2).
} 
their effects). Third, employers may offer education when low rates of participation and/or low contributions confound other objectives. Education may help employees to appreciate the substantial value associated with their 401(k) options (see Scott, 1995), and thereby reduce their demands for compensation in other forms. By promoting adequate preparation for retirement, an employer may also hope to avoid subsequent conflicts with older, poorly prepared workers. Assistance with financial planning may also enhance employee loyalty, improve labor relations, and boost morale. Fourth, if workers are interested in retirement planning, they may ask their employers to provide educational materials along with other benefits.

It is important to investigate the impetus for employer-based retirement education, as well as the factors that motivate individuals to make use of these programs, prior to studying the effects of this education on financial choices. Participation in an educational program, like participation in a $40 \mathrm{l}(\mathrm{k})$, is probably correlated with underlying tastes for saving and/or risk. Even the availability of education, like the availability of a $401(\mathrm{k})$, may be correlated with tastes. However, in contrast to the example of $401(\mathrm{k}) \mathrm{s}$, there is no presumption that eilher the receipt of, or eligibility for, retirement education is positively correlated with a predisposition to save. With respect to participation, those with sufficiently high propensities to save may choose not to make use of educational offerings simply because they have already informed themselves adequately on the subject of retirement. And with respect to availability, the sign of the correlation between education and underlying tastes for saving differs across the various hypotheses discussed above.

Under the first hypothesis, correlations between education and the predisposition to save may result from correlations between education and $40 \mathrm{l}(\mathrm{k})$ eligibility. However, this hypothesis has no implication concerning the sign of correlation between education and tastes conditional on the existence of a $401(\mathrm{k})$. Thus, as long as one controls for $40 \mathrm{l}(\mathrm{k})$ eligibility when studying financial behavior, the direction of the bias is not obvious. Under the second and third hypotheses listed above, education is remedial, and -- conditional on the existence of a $401(k)$-- tends to be offered more frequently in situations where employees are predisposed against saving. Consequently, if either of these hypotheses is valid, studies based on crosssectional data (including the current paper) will tend to be biased against the finding that education stimulates 
saving. Under the fourth hypothesis listed above, the resulting bias might well work in the opposite direction, since high-saving employees may be more likely to demand investment education as a fringe benefit.

In a related paper, Bayer, Bernheim, and Scholz [1996] investigate these hypotheses using data on a sample of employers surveyed by KPMG Peat Marwick in 1993 and 1994. They find that low rates of participation among non-highly compensated employees significantly increase the likelihood that employers will establish or enhance educational offerings. No other variable compares in importance as a predictor of subsequent educational activity. This evidence is most consistent with the third hypothesis mentioned above, and supports the view that educational offerings tend to be associated with a predisposition against saving.

The remainder of this section investigates the factors that influence the availability of financial education in the workplace, and the decision to make use of this education. It sheds additional light on the relative merits of the four hypotheses discussed above, as well as on the nature of correlations between the receipt and availability of education, and the underlying predisposition to save.

\section{A. Availability of employer-based retirement education}

A strong relation between the availability of education and pension eligibility is apparent in the raw data. Overall, just over one-half (53.5\%) of respondents report that their employers offer some form of retirement education. Of those without pensions, only $26.6 \%$ say that educational programs are available. In contrast, $68.9 \%$ of those covered only by $401(\mathrm{k}) \mathrm{s}, 58.0 \%$ of those covered only by other pension plans, and $76.4 \%$ of those covered by both types of plans report the existence of educational options. ${ }^{12}$ Since these options have become common even in the absence of $401(\mathrm{k}) \mathrm{s}$, the growth of self-directed plans does not appear to be the sole factor motivating the growth of retirement education in the workplace. ${ }^{13}$

\footnotetext{
${ }^{12}$ A relatively small number of those who describe themselves as "not working" nevertheless report that their employers offer some form of retirement education. These respondents may have in mind educational programs offered by past employers, their spouse's employer, or a school that they attend.

${ }^{13}$ Conceivably, "other pensions" may include some self-directed plans. However, our " $40 \mathrm{l}(\mathrm{k})$ " category is intended to include "other tax-defeited salary reduction plans," which subsumes many other common self-directed plans, such as 403(b)s. Of course, some respondents may have misclassified their pensions, but misclassification would have to be extremely common to explain the observed differences between those with and without other pensions. Notably, Bayer, Bernheim, and Scholz (1996) conroborate our findings using employer survey data.
} 
Table 3 contains estimates of probit models explaining the availability of retirement education at the respondent's workplace. Observations were dropped if the respondent was not employed or answered "don't know" or "refused" to any of the questions used to elicit the values of the explanatory variables. These variables fall into four categories: information on pension eligibility, demographic characteristics, aspects of employment, and "other," which includes a constant and taste proxies, discussed below.

Equation (1) explores the relation between the availability of education, characteristics of the respondent's job, and demographics. We include the demographic variables because they may be related to the type of job held by the respondent; it is also conceivable that they may be related to tastes, and that the coefficients of these variables may reflect self-selection among employment opportunities. Equation (1) omits three variables that we regard as more straightforward proxies for tastes (SE40IK, TSCORE, and PARSAVE). The estimates reveal that, as expected, workers with pensions are much more likely to have access to retirement education.. While the existence of a $401(\mathrm{k})$ plan is particularly important, the presence of other pensions is also strongly related to educational offerings. The relative sizes of the coefficients for ROPEN and R2PENS indicate that the existence of another pension plan on top of a 401(k) contributes significantly to the probability that retirement education is available. Women, non-whites, highly educated individuals, and highly compensated individuals are significantly more likely to work for employers who offer retirement education. There is little evidence that education is more widely available for older workers: while the coefficient of RAGE is positive, it lacks statistical significance.

Equation (2) adds three variables that arguably proxy for tastes, in an attempt to illuminate the relation between the availability of education and underlying tastes for saving. The first, TSCORE, measures the respondent's economic and financial knowledge. Respondents with higher values of TSCORE tend to have significantly greater wealth (see section 5). Thus, either TSCORE measures an aspect of tastes for saving (financial literacy), or it is correlated with unobserved characteristics that determine tastes for saving. One potential difficulty with the inclusion of TSCORE is that retirement education may improve economic and financial knowledge. However, the direction of the resulting bias is clear: if there is no correlation 
between the availability of education and tastes for saving, the coefficient of TSCORE would be positive. Unless education impairs economic literacy (which seems very unlikely), a negative coefficient would support the premise that education is typically provided as a remedial measure to those who are less inclined to save.

The second variable, PARSAVE, proxies for saving by the respondent's parents. PARSAVE should be correlated with tastes as long as tastes are, at least to some extent, inherited from parents either through "genes" or childhood experiences. There is no reason to expect that the correlation between rates of saving by parents and children would necessarily be positive. For example, respondents with frugal parents might be inclined to save less than others if they expect to receive large inheritances. However, in practice, there is a strong positive correlation between wealth and PARSAVE (see section 5).

The third variable, SE40IK, indicates whether the respondent's spouse is eligible for a $40 \mathrm{l}(\mathrm{k})$. Since SE40IK (unlike RE401K) is not an attribute of the respondent's job, it should have no direct effect on the presence or absence of education at the respondent's workplace. It may, however, have an indirect effect. Several authors (including Bernheim, 1994b, 1996, and Engen, Gale, and Scholz, 1994) have argued that 401(k) eligibility is positively correlated with the predisposition to save. If this is correct, then SE40IK should be a reasonable proxy for tastes as long as household financial decisions are influenced by the preferences of both spouses, or as long as tastes are correlated across spouses. ${ }^{14}$

The addition of these taste proxies does not significantly alter any of the results discussed above (compare equations (1) and (2) in table 3). The coefficient of TSCORE is negative, large in absolute value relative to those of other important explanatory variables, and statistically significant at a high level of confidence. The coeflicient of SE401K is also negative, but statistically insignificant, while the coefficient of PARSAVE is positive and statistically insignificant. This pattern of coefficients suggests that the presence of retirement education is negatively correlated with the predisposition to save.

\footnotetext{
${ }^{14}$ Conceivably, SE401 K may also be correlated with aspects of the respondent's job (since $40 \mathrm{l}(\mathrm{k})$ eligibility is correlated with characteristics, such as skills, that may affect assortive matching); however, it is unlikely that significant systematic correlations exist once one controls for the respondent's eamings, education, pension status, and other characteristics.
} 
To further examine the legitimacy of this inference, we performed the same exercise for a probit model explaining the respondent's $40 \mathrm{l}(\mathrm{k}$ ) eligibility. It would be implausible to suggest that $401(\mathrm{k})$ eligibility is negatively correlated with the predisposition to save. Thus, if TSCORE, PARSAVE, and SE40IK do indeed proxy for tastes, their coefficients should be zero or positive, in sharp contrast to the results obtained for educational offerings. Controlling for the same set of variables as in table 3 , we find that the coefficients of TSCORE and SE401K are both positive and significant at exceptionally high levels of statistical confidence, while the coefficient of PARSAVE is negative but statistically insignificant (we have omitted the estimated equations to conserve space). These results are at least consistent with the view that $401(\mathrm{k})$ eligibility (unlike the availability of education) is positively correlated with the predisposition to save. ${ }^{15}$

\section{B. Usage of employer-based retirement education}

Overall, $77 \%$ of respondents with access to retirement education in the workplace report that they make use of these opportunities. This is lower than the $92 \%$ figure (which refers to the fraction of workers who read written materials provided by their employers) reported by EBRI (1994). The usage rate is higher for workers covered only by $401(\mathrm{k}) \mathrm{s}(79.9 \%)$ than for workers without pensions $(69.1 \%)$. However, those covered only by pensions other than $40 \mathrm{l}(\mathrm{k}) \mathrm{s}$ are no more likely to participate in educational programs than those who have no pension coverage $(69.2 \%$ vs. $69.1 \%)$, and those with both $40 \mathrm{l}(\mathrm{k}) \mathrm{s}$ and some other plan are no more likely to participate than those covered by $40 \mathrm{l}(\mathrm{k}) \mathrm{s}$ alone $(80.2 \% \mathrm{vs} .79 .9 \%)$. Thus, the existence of a pension plan does not appear to affect the likelihood of worker participation in retirement education offerings unless the plan has self-directed features that require active participant decision-making.

These same patterns are evident in estimates of a probit model explaining the decision to use educational offerings, conditional upon availability (table 3, equation (3)). While the coefficient of RE40IK

\footnotetext{
${ }^{15}$ This evidence is by no means conclusive. If $401(\mathrm{k}) \mathrm{s}$ encourage greater saving, then they may also induce individuals to acquire greater financial knowledge. This would account for the positive correlation between $401(\mathrm{k})$ eligibility and TSCORE. The correlation with SE40IK is more difficult to explain, particularly given that we have controlled for a range of respondent characteristics, including eamings and education. To some extent, the correlation may be attributable to households in which the husband and wife have the same employer, but we doubt that this circumstance is sufficiently common to explain the magnitude of the estimated coefficient.
} 
is large and statistically significant, the coefficients of ROPEN and R2PENS are not. This finding contrasts with our results regarding the factors that determine the existence of educational programs (section $\mathrm{A}$ ).

It is also instructive to compare the coefficients of the other explanatory variables in equations (1) and (3). While women and non-whites are more likely to work for employers who offer retirement education, their usage rates are not higher. Educational offerings are more common for those with higher eamings, but participation is not. Married individuals are more likely to participate (the difference between married and single respondents being significant at the $90 \%$ level of confidence), but not more likely to work for an employer who offers retirement education. And while RED and RPART emerge with coefficients of the same sign in both equations, the estimates are imprecise. Overall, the dissimilarity of coefficients between these two regressions suggests that the existence of retirement education in the workplace is not demand driven -factors affecting the pattern of availability appear largely unrelated to factors affecting the pattern of usage. Analogously to section A, we also add our taste proxies (TSCORE, PARSAVE, and SE401K) to investigate the possibility that the use of retirement education is correlated with underlying tastes for saving. In this context, it may be less appropriate to think of SE40IK as proxying for taste, since its coefficient may reflect a behavioral response: respondents may choose to participate in educational programs to learn how to manage their spouse's $40 \mathrm{l}(\mathrm{k})$ assets. Indeed, the coefficient of SE40IK in equation (4) is positive, but insignificant. While the coefficients of TSCORE and PARSAVE also lack statistical significance, both are nevertheless negative. As before, if education improves economic and financial knowledge, we would expect to observe a positive coefficient for TSCORE unless participation is negatively correlated with innate sophistication. Since all three variables are strongly related to wealth and saving (see section 5), and since TSCORE and SE401K are strongly related to the respondent's 401 (k) eligibility, these results suggest that participation is not positively correlated with the predisposition to save. We are only moderately surprised by this finding. Those who are most inclined to save may have already educated themselves, and may view the low-level, remedial financial education offered by most employers as redundant. 


\section{Sources of Information and Advice}

A central objective of this paper is to determine whether employer-provided financial education influences employee behavior. Education might not affect behavior for a number of reasons. Workers might simply ignore it if they are uninterested, unmotivated, unable to understand it, or already well-informed. A more subtle possibility is that the information provided by employers might substitute for information that employees would have obtained from other sources. For example, an employee offered free investment counseling might stop paying for the advice of a financial planner. If this kind of substitution occurs, then employer-based financial education may serve as a tax-favored form of in-kind compensation, rather as an activity that should be expected to measurably alter the financial choices of employees.

While it is essential to examine actual bchavior, our survey also permits us to investigate directly the extent to which employees rely on employer-provided education and to measure the displacement of other information sources. Specifically, each respondent was asked to name the household decision-maker's most important source of advice and information on retirement planning. Respondents were offered fourteen possible answers, as well as the opportunity to provide an "open" response. We recoded these responses into six categories: employer, financial professional, parent/friend/relative, print media, own judgement, and other.

The first two columns of table 4 contain data on the distribution of primary sources of information and advice, tabulated separately according to whether the respondent's employer offered financial education. When education is offered, $27.0 \%$ of respondents report relying primarily on their employers, compared with only $7.4 \%$ of employees in instances where employer-based education is not offered. Thus, many employees apparently regard employer-based financial education as a critical source of information and advice.

A comparison of the distribution of primary sources of assistance for those with and without employer-based financial education provides some evidence on the extent to which this education displaces other specific sources of assistance. The fractions relying on parents/friends/relatives, own judgement, and "other" sources are much lower in the presence of educational programs, while the fractions relying on arguably authoritative sources (financial professionals and print media) are only slightly smaller. This 
pattern suggests that, for the most part, employer-based education may displace less authoritative sources of assistance. If so, there is a greater likelihood that the behavioral effects of education are significant.

Of course, these simple tabulations may be misleading. In section 3, we found that respondents' characteristics differ systematically according to whether employer-based education is available. For example, education is offered more frequently when the respondent's employer provides a $401(\mathrm{k})$.

Employees who are eligible for $40 \mathrm{l}(\mathrm{k}) \mathrm{s}$ tend to have higher incomes, more education, and greater financial sophistication. They also tend to rely on more authoritative sources when making financial decisions. Thus, raw statistics may understate the extent to which employer education supplants authoritative sources.

To control for these other factors, we estimated a multinomial logit equation explaining the respondent's primary source of assistance as a function of education, pension eligibility, demographic characteristics, employment information, and similar characteristics for spouses (when present). To conserve space, we omit the full set of parameter estimates, and instead summarize our central results as follows. Setting OEBRE equal to zero, we use the parameter estimates to fit a probability distribution over sources of assistance for each observation in our sample. We then average these probabilities across observations to create a fitted population distribution. Next, we set OEBRE equal to one and repeat the calculations. Results are reported in the two rightmost columns of Table 4 . Slightly less than half (8.1 percentage points) of the 16.7 percentage point increase in reliance on employers reflects displacement of authoritative sources (financial professionals and print media). The remaining $8.6 \%$ reflects displacement of parents/friends/ relatives, the respondent's own judgement, or "other" sources. Thus, although employer-based education displaces authoritative sources of assistance to a larger extent than was apparent from the raw data, displacement of non-authoritative sources appears to be more common. This finding supports the view that education has significant potential to influence behavior.

The full set of multinomial logit coefficients are difficult to interpret since the impact of any variable on the use of any particular source of assistance cannot be inferred from any one coefficient. We therefore estimate six separate probit equations -- one explaining the use of each information source -- and report 
results in Table 5. Note that the coefficient of education is large, positive, and statistically significant in the equation explaining reliance on employers. This finding is inconsistent with the view that employees ignore employer-provided education. Education also has a negative and statistically significant effect on the use of print media, the respondent's own judgement, and "other" sources of assistance.

Although we are primarily interested in the effects of education, other patterns are of independent interest. Respondents with pension coverage rely less on parents/friends/relatives, and more on print media. Women appear more likely to rely on employers, financial professionals, and parents/friends/relatives, but less likely to rely on print media and their own judgement. ${ }^{16}$ More highly educated individuals depend more heavily on financial professionals and print media, and less on employers and other sources. Reliance on parents, friends, and relatives declines with age. As one might expect, the self-employed are less likely to say that they rely on assistance from employers, ${ }^{17}$ as are those who work part-time or not at all (though the coefficients of these last two characteristics are only marginally significant).

We conclude that many employees rely heavily on financial education in the workplace, and that this education most commonly displaces non-authoritative sources of assistance (though significant displacement of authoritative assistance also occurs). . Thus, there is considerable scope for employer-based education to affect financial choices

\section{The Effect of Retirement Education on Household Saving}

We now turn to the critical question of whether retirement education in the workplace significantly affects saving behavior. In this section, we investigate the relation between employer-based education and four different behavioral variables: total net worth (TW), the total value of all assets which the respondent characterizes as savings for retirement (RW), saving for all purposes expressed as a fraction of current

\footnotetext{
${ }^{16}$ Conceivably, differences in repoited usage by gender may reflect differences in reporting, rather than differences in usage. For example, men may be more likely to credit their own judgement after the fact.

${ }^{17}$ When a self-employed respondent reports relying on an employer, this may refer to a spouse's employer, or to educational programs set up primarily for the respondent's employees.
} 
income (TSAVE), and saving for the purpose of retirement expressed as a fraction of current income (RSAVE). The first two variables measure stocks of wealth, while the last two measure flows.

The use of information on flow saving is particularly important in this context. As mentioned in section 1 , most retirement education programs have not existed for very long. The effect of education on flows should be proportionately larger, and more easily detectable, than the effect on stocks of wealth because stocks reflect all past choices, including those made prior to the availability of education. Also recall that the existence of financial education is negatively correlated with the predisposition to save (see section 3 or Bayer, Bernheim, and Scholz, 1996). Thus, in cases where educational programs are sufficiently recent, stocks of wealth may actually be lower for those who have access to employer-based education, even if education stimulates rates of saving. These considerations are less problematic for retirement wealth than for total wealth since stocks of retirement wealth are typically very low to begin with (a given change in rate of flow should manifest itself more quickly in the stock when the range of initial stocks is small).

This discussion suggests a procedure for distinguishing between causal hypotheses. If education stimulates saving, and if it is negatively correlated with the underlying inclination to save, its estimated effect on flow saving should be particularly pronounced, and its impact on retirement wealth should also be detectable. Education may nevertheless appear unrelated to, or even negatively correlated with, total net worth. Moreover, it would be difficult to account for this pattem under any other hypothesis. For example, if education is ineffective but positively correlated with the innate inclination to save, one would observe positive and equally strong effects for all of our dependent variables.

Several important issues arise with respect to the use of the flow variables. First, self-reported rates of saving are suspect because they do no necessarily reflect the consistent application of economically appropriate concepts. For example, some individuals may report the fractions of their paychecks that they put away, while others may (despite the wording of the questions) count some portion of reinvested capital 
income (e.g, realizations) as both income and saving. ${ }^{18}$ This disadvantage is at least partially offset by the fact that questions about rates are less invasive than questions about asset values; as a result, one obtains higher response rates, and possibly more honcst answers. It is also obvious from the results reported in this section that the variables TSAVE and RSAVE contain more than random noise. They are highly correlated with total net wealth (presumably reflecting serial correlation in rates of saving), and they exhibit the expected correlations with variables such as $40 \mathrm{l}(\mathrm{k})$ eligibility and education, even controlling for wealth. Absent either a true pancl or a detailed log of household spending, self-reported rates of saving are the only available measures of flow saving. While TSAVE and RSAVE are imperfect, they do appear to provide meaningful information on flow saving, and are therefore worthwhile subjects of analysis.

Second, the distinction between total wealth and retirement wealth, and the analogous distinction between the overall rate of saving and the rate of saving for retirement, may be imprecise and subjective. Some individuals may earmark funds for particular purposes, while others may regard their resources as fungible. While these distinctions are sharper when individuals use targeted retirement savings vehicles (e.g. IRAs, $401(k)$ s, variable annuities, and life insurance products), some individuals may save for retirement through other vehicles, or save for other objectives (such as college education) through a retirement account. Despite these issues, high response rates indicate that most individuals do have a sense about the portions of their wealth and flow saving that are psychologically, if not physically, earmarked for retirement.

In examining the relation between saving behavior and education, one must also be cognizant of the fact that the response to education may vary systematically across the population. While most Americans probably save too little, some save adequately, and a few probably put away significantly more than is necessary. If education nudges each household toward an appropriate mode of behavior, its impact on low and average savers may bear little resemblance to its impact on high savers -- even the sign of the effect may

\footnotetext{
${ }^{18}$ It is worth noting that no respondent reports negative saving, despite the fact that some households undoubtably dissave. This probably reflects the fact that most individuals do not think about saving and dissaving symmetrically. For those who dissave, it is probably more natural to report that they save nothing (a saving rate of zero) than to report a negative rate of saving.
} 
differ. For this reason, it is very important to distinguish between mean effects and quantile effects.

Traditional regression techniques such as OLS may systematically understate the importance of education precisely because the effect of education on mean saving is diluted by the response (or lack thereof) among those who already save enough. A separate but related concern is that, due to the pronounced skewness in the distributions of reported wealth and rates of saving, OLS estimates may be driven by the behavior of a relatively small number of individuals with the greatest inclination to save. For these reasons, we rely in this section primarily on quantile regression techniques (although, for completeness, we also report OLS results).

Before discussing the regression results, it is useful to summarize the key patterns in the raw data. The median ratio of total net worth to yearly earnings is lower for those whose employers offer retirement education (1.76) than for those whose employers do not (1.97). It is also lower for those who make use of these offerings (1.75) than for those who either do not make use of, or do not have access to such programs (1.89). These findings are difficult to reconcile with the hypothesis that education is positively correlated with the underlying inclination to save; indeed, they support the opposite inference.

It is therefore quite striking that much different patterns emerge for retirement wealth and flow saving. The median ratio of retirement wealth to annual earnings is higher when the respondent's employer offers retirement education ( 0.353 vs. 0.192 ). It is also higher for those who make use of these offerings than for those who do not $(0.364$ vs. 0.195$)$. Median rates of saving and rates of saving for retirement are also higher for those who have access to retirement education programs ( $10 \%$ and $5 \%$, respectively) and for those who make use of these programs (again, $10 \%$ and $5 \%$ ) than for those who are ineligible $(6 \%$ and $3 \%$ ), and for those who are either ineligible or who don't participate (6\% and $4 \%)$.

The patterns in the raw data coincide with those predicted at the outset of this section, under the hypothesis that retirement education is remedial (and therefore negatively correlated with the predisposition to save) and effective at stimulating saving. In light of the negative correlation between retirement education and total wealth, it is difficult to rationalize the positive correlations between educational offerings, retirement wealth, and flow saving as consequences of a spurious relation between these offerings and tastes for saving. 
Of course, the raw statistics may be misleading. As shown in section 3, educational offerings are correlated with other factors that may influence saving. It is therefore important to determine whether the central empirical patterns survive once one properly controls for a range of pertinent characteristics.

Table 6 contains four median regressions -- one for each dependent variable. The explanatory variables include the availability of retirement education in the workplace (OEBRE), pension characteristics for both respondent and spouse (if any), the demographic characteristics of both respondent and spouse, characteristics of employment for both respondent and spouse (earnings and work status), and "other" controls, including taste proxies (TSCORE and PARSAVE) and the log of total wealth (LOGTW). LOGTW is, of course, not included in the regressions that explain stocks of wealth. Its inclusion in the specifications explaining flow saving is justified by the usual life cycle considerations, which imply that its coefficient should be negative (since higher wealth should increase consumption). However, if preferences towards saving are reasonably stable over time, it may be more appropriate to think of LOGTW as another taste proxy, in which case one would expect a positive coefficient. Table 7 presents analogous results for UEBRE.

The use of both OEBRE and UEBRE requires some comment. Conceptually, it may seem more appropriate to control for participation in educational programs (UEBRE), rather than the mere availability of such programs (OEBRE). We are concerned, however, about endogeneity. While either variable may be correlated with factors that determine a respondent's underlying predisposition to save, this concern is more pronounced in the case of UEBRE. ${ }^{19}$ One can think of specifications that control for OEBRE as reduced forms, in which we have substituted an expression explaining UEBRE.

In the specification for total wealth (Table 6), the coefficient of OEBRE is positive, though quite small in magnitude, and statistically insignificant. Thus, while the addition of other control variables (including taste proxies) eliminates the negative correlation between OEBRE and median wealth, there is no

\footnotetext{
${ }^{19}$ For OEBRE, the issue of endogeneity depends only on the factors that motivate an employer to offer financial education. If, as we have argued, education is remedial, the coefficient of OEBRE will be biased downward. With respect to UEBRE, the bias depends not only on the factors affecting the availability of education, but also on the characteristics that motivate an employee to use an available program.
} 
positive relation to speak of. In contrast, the estimated effect of OEBRE on median retirement wealth is large (nearly \$2,500) and statistically significant. The availability of retirement education also increases the overall rate of saving by 1.65 percentage points, and raises the rate of saving for retirement by just under one percentage point. Both effects are large relative to median rates of saving for those who do not have access to retirement education in the workplace ( 6 percent and 3 percent, respectively), and both are statistically significant at high levels of confidence. Notably, the estimated effect on the overall rate of saving is larger than the estimated effect on retirement saving. This suggests that retirement education may have a positive spillover effect on saving outside of retirement accounts.

We are again struck by the finding that education is strongly related to retirement wealth and flow saving, but not to total net worth. We reiterate that this is consistent with the pattern predicted at the outset of this section, but inconsistent with the hypothesis that education is correlated with unobserved tastes for saving. One might question this inference on the grounds that some spurious factor, such as poor measurement of total net worth, could explain the discrepancy. However, if this was the case, then one would also observe similar discrepancies for other variables. It is therefore notable that the coefficients of RE401K are all positive and statistically significant. Indeed, the coefficient of RE40IK in the specification for total wealth is particularly large. The coefficients of SE40lK exhibit a similar pattern.

It is tempting to interpret the coefficients of RE401K and SE401K as behavioral effects, and to conclude that $401(\mathrm{k})$ s also stimulate saving. Caution is warranted, however, since there is a strong presumption that the correlation between $40 \mathrm{l}(\mathrm{k})$ eligibility and the predisposition to save is non-negative. If anything, our results strengthen this presumption. Note that the coefficients of RE40lK and SE401K in the equation for total wealth are nearly four times as large as the corresponding coefficients in the equation for retirement wealth. If we interpret these coefficients as behavioral effects, we would be forced to conclude that $40 \mathrm{l}(\mathrm{k}) \mathrm{s}$ crowd in other saving at the astonishing rate of four to one. Strictly speaking, this finding does not rule out a behavioral interpretation; for example, it is consistent with a powerful "recognition effect." However, if such an effect exists, it is difficult to understand why the effect of the respondent's $40 \mathrm{I}(\mathrm{k})$ 
eligibility on the total saving rate is less than its effect on the retirement saving rate (which implies some crowding out, rather than crowding in). We are therefore inclined to attribute some unknown portion of the coefficients for $401(\mathrm{k})$ eligibility to correlations with unobserved tastes.

Since our focus is on the effects of financial education, we will touch only briefly on the other coefficients reported in table 6 . Eligibility for other pensions is associated with greater wealth and higher rates of saving, although none of the estimated effects (with the exception of ROPEN in the equation for retirement wealth) is statistically significant. The interpretation of the coefficients for the marital status dummy (which are statistically significant in the wealth equations) is obscure, since all variables measuring spousal characteristics are given fixed default values (usually zero) for single individuals. The coefficients of FEMALE and BLACK are uniformly negative, but lack statistical significance. General education is positively related to wealth for both the respondent and spouse, and to flow saving for the respondent (the relations between flow saving and spouse's education are statistically insignificant). ${ }^{20}$ Wealth is strongly related to age, but flow saving is not; there is very little evidence that rates of saving accelerate over the age range covered by our sample. Earnings are positively related to wealth, but there is only weak evidence that the rate of saving rises with earnings. Self employed individuals have more total wealth (typically in the form of businesses), but they do not have more retirement wealth, and they do not tend to save at higher rates (the associated coefficients are negative and statistically insignificant). Not surprisingly, part-time employees save at significantly lower rates. However, there is no indication that they have less wealth. ${ }^{21}$ One-eamer households have greater wealth, but they do not appear to save at higher rates. ${ }^{22}$

\footnotetext{
${ }^{20}$ There are many possible explanations for this linding. General education may proxy for permanent income, or for patience; it may also provide analytic skills that contribute to more deliberate decision-making.

${ }^{21}$ There are several possible explanations for this finding. First, recall that we control for eamings. Suppose that a part-time worker has the same earnings as a full time worker. If the part-time worker has worked full-time in the past, then he or she has greater past earnings. Thus, he or she might well have greater wealth. Second, the decision to work part-time may be endogenous. An individual may select this option only if he or she has sufficient resources to afford it.
}

${ }^{22}$ One can explain this finding analogously to the coefficients of RPART and SPART. Holding current earnings constant, one-earner households may have higher past earnings than two-eamer households, since the nonworking spouse may have worked in the past. Alternatively, having one spouse stay at home may be a luxury, chosen 
Our taste proxies uniformly have the expected signs. In the total wealth and retirement wealth specifications, the coefficients of both TSCORE and PARSAVE are large and statistically significant at high levels of confidence. While the statistical significance of these variables is diminished in the saving rate regressions (PARSAVE remains significant, while TSCORE does not), this is in part due to the inclusion of LOGTW, which enters with positive and highly significant coefficients. This finding, which appears to contradict the implications of the life cycle hypothesis, implies that LOGTW acts as a superior taste proxy.

We obtain similar results for specifications that control for participation in educational programs (UEBRE, table 7). As with OEBRE, we find essentially no relation between UEBRE and total wealth. The coefficient of UEBRE is slightly smaller than that of OEBRE in the equation for retirement wealth (though still statistically significant), and larger in the equations for flow saving. The use of UEBRE, rather than OEBRE, does not dramatically alter the pattern of coefficients obtained for other variables.

To further investigate the robustness of our results, and to develop additional evidence concerning possible spurious relations between education and underlying preferences for saving, we conduct some additional exercises. To conserve space, we omit detailed results, and summarize key coefficients in table 8 .

We focus here on the specifications for flow saving, since this is where the effects of education are most pronounced. Table 8 is divided into four sections, which are distinguished according to whether the explanatory variables include OEBRE or UEBRE, and whether the dependent variable is TSAVE or RSAVE. Each of these sections contains the coefficients for education (OEBRE or UEBRE) and 40l(k) eligibility (RE40l(k) and SE40l(k)) from five equations. Each regression controls for the same set of explanatory variables used in tables 6 and 7, except where otherwise noted. For purposes of comparison, the first entry in each section provides the key coefficients from the "basic median regressions" reported in tables 6 and 7 .

We motivate our first robustness exercise as follows. If the availability and/or usage of education is correlated with underlying and (at least to some extent) unobserved preferences for saving, then, absent an ideal instrument, bias is inevitable. If education is negatively correlated with the predisposition to save, then 
the estimated effects of education should be biased downward, and the inclusion of taste proxies should reduce (but not eliminate) this bias. In contrast, if education is positively correlated with the predisposition to save, then the estimated effects of education should be biased upward, and the inclusion of taste proxies should again reduce (but not eliminate) this bias. Thus, we can shed light on the sign of the bias by omitting the taste proxics, and examining the resulting changes in the key coefficients. ${ }^{23}$

The second entry in each of the four sections of table 8 presents the key coefficients from a median regression in which we have removed the taste proxies (TSCORE, PARSAVE, and LOGTW). Note that, in every case, the estimated coefficient of education declines, while the coefficients of RE40l(k) and SE40l(k) increase. This contrast is significant because of the presupposition that $401(\mathrm{k})$ eligibility is positively (or at least not negatively) correlated with the predisposition to save. These findings provide further support for the hypothesis that both OEBRE and UEBRE are negatively correlated with the predisposition to save. We are therefore inclined to believe that even our basic median regressions understate the true impact of education.

Our second robustness exercise involves the estimation of quartile regressions for the 25 th and 75 th percentiles of the population distribution, as well as OLS regressions. The comparison of effects for different quartiles is of interest since, as noted previously, the impact of education should be most pronounced among low savers. The results in table 8 indicate that the effects of OEBRE and UEBRE on total flow saving are smaller at the third quartile ( 75 th percentile) than at the first quartile (25th percentile), as expected. In addition, the effects of education at the first quartile and at the median are statistically significant, whereas the effects at the third quartile are not. While the absolute effect of education does not decline monotonically

\footnotetext{
${ }^{23}$ The argument in the text abstracts from the possibility that certain taste proxies (TSCORE and LOGTW) may be affected by education and by underlying altitudes towards saving. This complicates, but does not fundamentally alter the logic of the exercise. Suppose that education increases saving. Consider two individuals with the same level of LOGTW, one of whom has received retirement education, and one of whom has not. On average, the one without retirement education must have a greater predisposition to save. Thus, controlling for LOGTW induces a negative partial correlation between education and the taste for saving, thereby biasing the coefficient of OEBRE (or UEBRE) downwards. A similar argument applies for TSCORE. The omission of the taste proxies eliminates this bias, but increases the bias associated with conelations between OEBRE (or UEBRE) and unobserved tastes. If education is negatively correlated with tastes for saving, then the two effects work in opposite directions, and the omission of the taste proxies can in principle move the coefficient of education in either direction. However, if education is positively correlated with tastes for saving, the two effects work in the same direction, and the omission of the taste proxies should unambiguously increase the coefficient of education.
} 
across quartiles (it is greater at the median than at the first quartile), one must keep in mind that respondents at the first quartile save very little to begin with (only about $2 \%$ of income in the absence of education, compared with $6 \%$ at the median). Thus, the first quartile effects represent larger proportionate increases than the median effects. A very different pattern of coefficients emerges for $401(\mathrm{k})$ eligibility. The magnitude of the coefficient for RE40l( $k$ ) is similar across quartiles -- there is no decline at the third quartile, although statistical significance is reduced. For SE401(k), by far the largest effect is found at the third quartile; indeed, no impact on saving at the first quartile is evident.

Table 8 also contains results for flow retirement saving. For both OEBRE and UEBRE, the estimated effects at the third quartile are similar to those at the median, and somewhat larger in magnitude than at the first quartile. However, when OEBRE is used, the effect at the third quartile is not statistically significant, whereas the effects at the median and first quartile are. Also, the proportional change in behavior is much larger at the first quartile. Again, these rcsults contrast sharply with our findings for $401(\mathrm{k}) \mathrm{s}$. The size of the estimated cocfficients for RE40I(k) and SE40I(k) increase monotonically as one moves from the first quartile to the median, and from the median to the third quartile.

The finding that education is generally less effective among those more inclined to save is consistent with our predictions, and provides additional evidence that our results are not attributable to spurious factors. Since the reasons for making this prediction are peculiar to education, we take further comfort from the fact that no such pattern is apparent for our measures of $401(k)$ eligibility.

We have included OLS regressions for the sake of completeness. The coefficients of UEBRE are smaller, but remain statistically significant. The coefficients of OEBRE are also smaller, and statistical significance is only marginal in the case of total flow saving. Since the skewness of saving causes OLS results to be disproportionately influenced by high savers, the weakening of our results is not surprising. For the reasons expressed earlier in this section, we believe that the quantile regressions provide more reliable and complete information on the effects of education. 


\section{401(k) Activity}

As discussed in section 3, the growth of employee-directed retirement plans has been a major factor contributing to the emergence of employer-provided financial education. It is therefore natural to investigate the behavioral consequences of education in the context of these plans.

Educational offerings are strongly correlated with participation in a $401(k)$ plan. Rates of reported participation are $83.5 \%$ among respondents when education is available, compared with only $70.4 \%$ when it is not. Of those who use educational offerings, $88.4 \%$ participate in $401(k)$ plans, while the participation rate is only $64.4 \%$ for those who have access to, but do not make use of these offerings. ${ }^{24}$ Account balances follow a similar pattern. When education is offered, the median $40 \mathrm{l}(\mathrm{k})$ balance for respondents (counting eligible non-participants as zeros) is $\$ 8,250$, compared with only $\$ 5,000$ among those for whom such programs are unavailable. Those making use of educational offerings have median plan balances of $\$ 10,000$, while those failing to make use of available education have median balances of only $\$ 4,000$.

It is also possible that the availability of education has a positive spillover effect on rates of participation in $401(\mathrm{k}) \mathrm{s}$ for spouses. Indeed, the participation rate for spouses is $86 \%$ when employerbased education is available to the respondent, compared with $74 \%$ when it is not available to the respondent. The difference in median balances is smaller for spouses than for respondents: $\$ 6,000$ when education is offered to the respondent, versus $\$ 5,000$ when it is not.

Of course, the subset of employees who have access to employer-based financial education is not typical of all those who are eligible for $40 \mathrm{l}(\mathrm{k}) \mathrm{s}$ (see section 3 ). Inasmuch as that subset tends to be less sophisticated and less pre-disposed to save, the raw correlations may understate the effects of education on participation. In the remainder to this section, we investigate the relation between education and plan

\footnotetext{
${ }^{24}$ Reported rates of participation in our sample (78\% for respondents, $79 \%$ for spouses) are slightly higher than estimates based on surveys of employers. Hewitt and Associates (1993) report average plan-weighted participation rates of $75 \%$; the average participant-weighted figure is $72 \%$. Papke, Peterson, \& Poterba (1993) calculate an average participation rate of $76 \%$ based on a small 1990 survey of employers. Some previous household surveys also yield lower participation rates. Poterba, Venti, and Wise (1993) report a rate of $70.8 \%$ based on 1991 data from the SIPP. Given that participation rates have been rising, our figures do not appear to be far out of line with past estimates.
} 
activity, controlling for other personal characteristics.

Ideally, one should control for plan features, such as the rate at which an employer matches contributions, as well as individual characteristics. The available evidence on the effects of these features is mixed..$^{25}$ If education is more common among employers who offer matching contributions, and if matching provisions increase participation, then our failure to control for match rates may impart an upward bias to the coefficient of education in our regressions. There is, however, no reason to assume that the correlation between match rates and education is positive. One might expect to observe a positive correlation if employers differ in their desire to make their plans attractive, and if those intent on enhancing their plans offer both education and matching. However, if employers view education and matching provisions as substitutable methods of stimulating participation (e.g. to satisfy non-discrimination requirements), then these provisions might be negatively correlated. In practice, employer survey data indicate that the correlation between matching and educational efforts is slightly negative, and statistically insignificant (see Bayer, Bernheim, and Scholz, 1996). Thus, the failure to control for matching is probably unimportant, and if anything may cause us to understate slightly the effects of education.

Other features of a $401(\mathrm{k})$ plan, such as loan provisions or the number and variety of investment options, may also influence participation. Bayer, Bernheim, and Scholz (1996) do find a small positive correlations between education and certain other plan features. However, on the basis of the existing evidence, it is doubtful that these other features dramatically affect participation or contributions; hence, their omission is probably not very important.

The first two columns in Table 9 contain estimates of probit specifications explaining the respondent's 401(k) participation, conditional on eligibility. The explanatory variables include our

\footnotetext{
${ }^{25}$ According to Papke, Peterson, \& Poterba (1993), the existence of matching contributions increases participation rates by 15 percentage points. They cannot, however, reject the hypothesis that participation rates are independent of the size of the match. Scott (1995) concludes that both the existence of a match, and the size of the match, are positively associated with participation. Papke (1992) finds that low match rates increase the share of salary contributed, but at high match rates (i.e. 50\%), there appears to be a negative effect. Andrews [1992] concludes that the existence of a match increases participation rates but decreases contribution levels.
} 
measures of education (OEBRE in equation (1), and UEBRE in equation (2)), other pension variables, demographic characteristics, aspects of employment, and two variables used as proxies for underlying tastes regarding saving (TSCORE and PARSAVE) ${ }^{26}$ Our central finding is that OEBRE and UEBRE both enter with large and highly statistically significant coefficients. This result is not sensitive to the inclusion of taste proxies. Indeed, in contrast to other measures of wealth and saving examined elsewhere in section 5 , the respondent's participation in $401(\mathrm{k})$ plans appears to be essentially unrelated to the taste proxies.

To provide some sense for the importance of education, we calculate fitted probabilities that the average eligible respondent would participate in his or her $401(\mathrm{k})$ plan when education is available (OEBRE equals 1 ), and when it is not available (OEBRE equals 0 ). The availability of education increases the fitted probability by 11.8 percentage points. We also conduct a similar calculation, fitting probabilities for each value of UEBRE. This exercise indicates that rates of participation are 19.5 percentage points higher for those who make use of education than for those who do not.

While we are primarily concerned with the effects of education, other aspects of the reported regressions are also of interest. Participation is less likely when the respondent is eligible for another pension plan, but the statistical significance of this result is marginal. Spouse's pension eligibility does not appear to affect respondent's participation. While neither marriage nor gender influences participation, blacks appear less likely to participate (with moderate statistical significance). Surprisingly, there is no significant tendency for participation rates to rise either with general education or age. Respondents with higher incomes are much more likely to participate, but spouse's income has little effect on respondent's participation.

We now turn our attention to the respondents' account balances. Following our previous practice, we initially present results based on median regressions. These are contained in the two rightmost columns of table 9 (equations (3) and (4)). The estimated effect of OEBRE on 401(k) balances is almost exactly the

\footnotetext{
${ }^{26}$ Here, we only retain the spousal characteristics that appear most pertinent. Symmetrically, we eliminate a number of respondent characteristics from specifications explaining spouse's $401(k)$ activity (table 10 ). None of the omitted enters with a statistically signilicant coefficient, or meaningfully affects the reported results.
} 
same as its effect on retirement wealth (table 6). The estimate is less precise (due to the reduction in sample size that results from confining attention to those eligible for $401(\mathrm{k}) \mathrm{s})$, but still significant at the $90 \%$ level of confidence. The coefficient of UEBRE is slightly larger than the corresponding effect on retirement wealth (table 6), and highly significant. As in section 5 (table 8), the omission of our taste proxies (TSCORE and PARSVE) reduces both the size and statistical significance of the coefficients of OEBRE and UEBRE (we omit details to conserve space). This pattern again suggests that our inability to control fully for tastes leads us to understate the true effects of education.

Table 9 reveals that accumulated balances rise significantly with the respondent's age and earnings. Part-time respondents also have larger accumulated balances (see footnote 21 for possible explanations). Aside from TSCORE, none of the remaining explanatory variables enter either specification with statistically significant coefficients.

Next, we investigate the possibility that education for the respondent has positive behavioral spillovers on spouse's $40 \mathrm{l}(\mathrm{k})$ activity. Results on participation and contributions are contained in table 10 (the structure of which parallels that of table 9). The estimated relation between education (OEBRE and UEBRE) and participation (equations (1) and (2)) is quite pronounced. Aside from OEBRE and UEBRE, very few explanatory variables enter these equations with statistically significant coefficients. Spouse's education and spouse's earnings are positively related to participation, and spouses who work part-time are less likely to participate. Just as spouse's earnings were poor predictors of the respondent's participation, respondent's earnings are poor predictors of the spouse's participation.

Equations (3) and (4) of table 10 reveal a small positive relation between the availability of education at the respondent's workplace and spouse's median $40 \mathrm{l}(\mathrm{k})$ balances. However, the coefficients of OEBRE and UEBRE are statistically insignificant. Our estimates of the specifications for spouse's 401(k) balances resemble the corresponding estimates for respondents (table 9, equations (3) and (4)) in that spouse's balances rise with spouse's age and earnings, but are unaffected by the respondent's characteristics. However, there are also a few differences. Spouse's balances fall when the spouse is 
eligible for another pension (perhaps indicating some degree of substitution), and rise with the spouse's education. Also, the coefficients of part-time work and TSCORE are insignificant. The latter finding perhaps indicates that TSCORE is a better proxy for the respondent's tastes than for the spouse's tastes.

Analogously to section 5, it is possible to shed further light on the relation between education and 401(k) balances by examining behavior at quantiles other than the median. There is, however, reason to anticipate a somewhat different pattern of coefficients in the current context. As in section 5, one would expect to find strong behavioral effects, both for respondents and for spouses, among those least inclined to save (that is, at lower quantiles). However, to the extent education promotes greater contributions from non-highly compensated employees, it relaxes the non-discrimination requirements that limit contributions by many aggressive savers. This in turn impels the constrained, aggressive savers to contribute more, regardless of whether they themselves actually use the education. ${ }^{27}$ These observations have specific and distinctive implications. At higher quantiles, we expect to find some relation between respondent's $401(\mathrm{k})$ balances and education, and this relation should be stronger for the availability of education (OEBRE) than for the usage of education (UEBRE). In contrast, since OEBRE pertains to the respondent's workplace, it cannot influence non-discrimination constraints at the spouse's workplace. We therefore expect to find little or no relation between spouse's $401(\mathrm{k})$ balances and measured education at higher quantiles.

We test these predictions in table 11 . To conserve space, we omit detailed regression results, and report only the coefficients of educational variables. For purposes of comparison, the table lists the pertinent coefficients from the "basic median regressions" of tables 9 and 10 , as well as coefficients for regressions at the first and third quartiles. For the respondent's plan balances, the effects of education (either OEBRE or UEBRE) are somewhat smaller in absolute value, but larger proportionately and considerably more significant statistically, at the 25 th percentile than at the median. We also find a statistically significant relation between spouse's plan balances and education at the 25 th percentile, even

\footnotetext{
${ }^{27}$ This might or might not show up as an increase in the rate of retirement saving, depending on the extent to which $401(\mathrm{k})$ saving displaces other retirement saving for highly motivated savers.
} 
though this effect was difficult to detect at the median. These findings strengthen our inference that the effects of education are most pronounced among those who are least inclined to save. As predicted, neither OEBRE nor UEBRE appear to affect spouse's plan balances at the 75th percentile. Similarly, the coefficient of UEBRE, though positive, is statistically insignificant in the corresponding equation explaining respondent's $40 \mathrm{I}(\mathrm{k})$ balances. However, the effect of OEBRE on respondent's balances is large and statistically significant at the 75 th percentile. It is difficult to account for this pattern unless the availability of education at the respondent's workplace relaxes non-discrimination requirements by encouraging contributions from low-saving, non-highly compensated employees.

Overall, the evidence indicates that employer-provided financial education significantly increases rates of participation in and contributions to $401(\mathrm{k})$ plans. Part of this effect appears to reflect the relaxation of non-discrimination constraints that would otherwise reduce the contributions of highly motivated savers. Education also has significant spillover effects on the participation rates of spouses, and on the plan balances of spouse's among those who are least inclined to save.

\section{Conclusions}

In this study, we have provided the first systematic evidence on the determinants and consequences of financial education in the workplace. Our analysis suggests that education is typically offered as a remedial measure, most commonly in the context of participant-directed pension plans. Holding the features of pension plans constant, education therefore tends to be inversely correlated with factors that predispose individuals toward saving. We find that significant numbers of employees rely heavily on employer-based financial education when it is made available to them. Moreover, although education replaces potentially authoritative sources of information and guidance (e.g. financial planners) to some extent, it primarily displaces sources of questionable reliability (e.g. parents and friends). Rates of saving, both in general and for the purposes of retirement, increase significantly with the provision of employer-based education. Employees who are offered retirement education are far more likely to participate in $40 \mathrm{l}(\mathrm{k})$ programs, and to 
make larger contributions to their plans. The effects of education are particularly pronounced among those least inclined to save; however, there is some indication that education stimulates $401(\mathrm{k})$ contributions among high savers by relaxing non-discrimination constraints.

One possible criticism of this analysis is that education may change the way individuals think about and report saving, rather than the way they behave. We are inclined to discount this hypothesis, on the grounds that it provides far less natural explanations for the differentials between the effects of education on flow saving and stocks of wealth, on retirement savings and net worth, and on low savers and high savers. Nor does it account adequately for the impact on $401(\mathrm{k})$ participation, ${ }^{28}$ or the distinctive effect of availability (rather than usage) on the $40 \mathrm{l}(\mathrm{k})$ contributions of aggressive savers. It is also noteworthy that results based on employer surveys corroborate our central findings for $401(\mathrm{k}) \mathrm{s}$ (see Bayer, Bernheim, and Scholz, 1996).

Our analysis has potentially important implications conceming the efficacy of strategies to stimulate saving by U.S. households. Most obviously, it raises the prospect that a serious national campaign to promote saving through education and information could have a measurable impact on behavior. Since many employers are apparently inclined to offer retirement education in the workplace, the Department of Labor could speed this process by taking more aggressive steps to alleviate the concern that the provision of education might trigger fiduciary liabilities under ERISA.

\footnotetext{
${ }^{28}$ Education probably increases awareness of $40 \mathrm{l}(\mathrm{k})$ plans among non-participants. Thus, if it has no effect on actual participation, one would expect it to reduce measured participation.
} 


\section{References}

A. Foster Higgins \& Co., Inc. Survey of Employee Savings Plans, 1994, Report 2: Plan Participation and Discrimination Testing, Princeton, NJ: A. Foster Higgins \& Co., Inc., 1994.

Bayer, Patrick J., B. Douglas Bernheim, and J. Karl Scholz, "The Effects of Financial Education in the Workplace: Evidence from a Survey of Employers," 1996, in progress.

Berg, Olena, "DOL to Launch Savings and Pension Education Campaign," EBRI Notes, June 1995, p. 2.

Bernheim, B. Douglas, The Vanishing Nest Egg: Reflections on Saving in America, New York: Priority Press, 1991.

Bernheim, B. Douglas, "Personal Saving, Information, and Economic Literacy: New Directions for Public Policy," in Tax Policy for Economic Growth in the 1990s, Washington, DC: American Council for Capital Formation, 1994a, 53-78.

Bernheim, B. Douglas, "Comments and Discussion," Brookings Papers on Economic Activity (1), 1994b, 152-166.

Bernheim, B. Douglas, "Do Households Appreciate Their Financial Vulnerabilities? An Analysis of Actions, Perceptions, and Public Policy," Tax Policy and Economic Growth, Washington, DC: American Council for Capital Formation, 1995a, pp. 1-30.

Bernheim, B. Dougłas, "The Merrill Lynch Baby Boom Retirement Index: Update '95," mimeo, 1995b.

Bernheim, B. Douglas, "Rethinking Saving Incentives," in Alan Auerbach (ed.), Fiscal Policy: Lessons from Economic Research, Cambridge, MA: MIT Press, 1996, forthcoming.

Bernheim, B. Douglas and J. Karl Scholz, "Private Saving and Public Policy," Tax Policy and the Economy 7, 1993, 73-110.

Borleis, Melvin W., and Kimberly K. Wedell, "How to spark employee interest with employer matching contributions," Profit Sharing, January 1994, pp. 7-16.

Central Council for Savings Promotion, Savings and Savings Promotion Movement in Japan, Tokyo: Bank of Japan, 1981.

Congressional Budget Office, Baby Boomers in Retirement: An Early Perspective, September 1993.

Employee Benefit Research Institute, Retirement Confidence in America: Getting Ready for Tomorrow, EBRI Special Report SR-27, Issue Brief Number 156, December 1994.

Employee Benefit Research Institute, "Can We Save Enough to Retire? Participant Education in Defined Contribution Plans," EBRI Issue Brief, no. 160, April 1995.

Engen, Eric M., William G. Gale, and John Karl Scholz, "Do Saving Incentives Work?" Brookings Papers on Economic Activity (1), 1994, 85-151. 
Garrett, Daniel M., "The Effects of Nondiscimination Rules on 401 (k) Contributions," mimeo, Stanford University, 1995.

Geisel, Jerry, "Communication yields success for XTRA 401(k)," Business Insurance, April 10, 1995, p. 3.

Hubbard, R. Glenn, Jonathan Skinner, and Stephen P. Zeldes, "Precautionary Saving and Social Insurance," Journal of Political Economy, 103(2), April 1995, 360-399.

Scott, Jason, “The Compensation Value of 40 l(k) Pension Plans," mimeo, Stanford University, 1994. 
Table 1: List of Variables

\begin{tabular}{|c|c|c|c|}
\hline \multicolumn{2}{|c|}{ Variable Name } & \multirow{2}{*}{$\begin{array}{l}\text { Definition } \\
\text { Respondent offered employer-based } \\
\text { retirement education }\end{array}$} & \multirow{2}{*}{$\begin{array}{c}\text { Type } \\
\text { Binary }\end{array}$} \\
\hline Education & OEBRE & & \\
\hline & UEBRE & $\begin{array}{l}\text { Respondent uses employer-based } \\
\text { retirement education }\end{array}$ & Binary \\
\hline \multirow[t]{8}{*}{ Pensions } & RE40IK & Respondent eligible for $401(k)$ & Binary \\
\hline & SE401K & Spouse eligible for $401(k)$, spouse & Binary \\
\hline & RP401K & Respondent participates in $401(\mathrm{k})$ & Binary \\
\hline & SP401K & Spouse participates in $401(\mathrm{k})$ & Binary \\
\hline & RB40IK & Respondent's balances in $401(\mathrm{k}) \mathrm{s}$ & Continuous \\
\hline & SB401K & Spouse's balances in $401(\mathrm{k}) \mathrm{s}$ & Continuous \\
\hline & ROPEN & Other pension, respondent & Binary \\
\hline & SOPEN & Other pension, spouse & Binary \\
\hline \multirow[t]{8}{*}{ Demographics } & MAR & Marital status & Binary \\
\hline & FEMALE & Gender & Binary \\
\hline & BLACK & Black respondent & Binary \\
\hline & OTHER & Other non-white respondent & Binary \\
\hline & RED & Formal education, respondent & Categorical \\
\hline & SED & Formal education, spouse & Categorical \\
\hline & RAGE & Age, respondent & Continuous \\
\hline & SAGE & Age, spouse & Continuous \\
\hline \multirow[t]{8}{*}{ Employment } & LREARN & Log of annual earnings, respondent & Continuous \\
\hline & LSEARN & Log of annual earnings, spouse & Continuous \\
\hline & RSE & Self-employment, respondent & Binary \\
\hline & SSE & Self-employment, spouse & Binary \\
\hline & RPART & Part-time worker, respondent & Binary \\
\hline & SPART & Part-time worker, spouse & Binary \\
\hline & RNOWORK & Not employed, respondent & Binary \\
\hline & SNOWORK & Not employed, spouse & Binary \\
\hline \multirow[t]{2}{*}{ Saving(s) } & TW & Total net worth & Continuous \\
\hline & LOGTW & Log of total net worth & Continuous \\
\hline
\end{tabular}

\section{Continued}




\begin{tabular}{|c|c|c|c|}
\hline & Variable Name & Definition & Type \\
\hline Other & $\begin{array}{l}\text { RW } \\
\text { TSAVE } \\
\text { RSAVE } \\
\text { PARSAVE } \\
\text { TSCORE }\end{array}$ & $\begin{array}{l}\text { Total savings for retirement } \\
\text { Overall rate of saving (as a fraction of } \\
\text { annual income) } \\
\text { Rate of saving for retirement (as a } \\
\text { fraction of annual income) } \\
\text { Parents' inclination to save } \\
\text { Normalized score on } \\
\text { economic/financial test questions }\end{array}$ & $\begin{array}{l}\text { Continuous } \\
\text { Continuous } \\
\text { Continuous } \\
\text { Categorical } \\
\text { Continuous }\end{array}$ \\
\hline
\end{tabular}


Table 2: Comparisons with Benchmarks

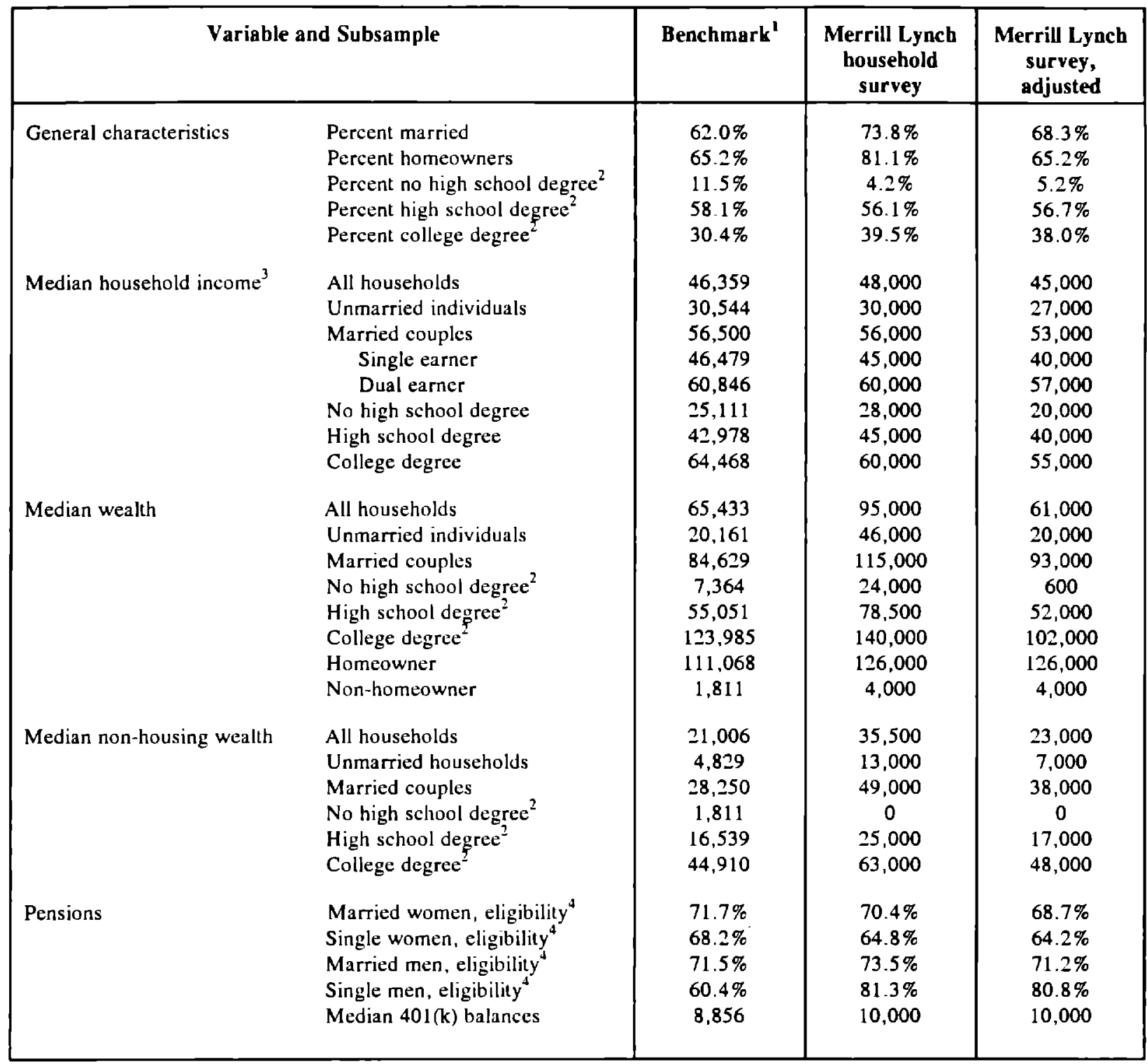

Notes: 1. For general characteristics, median household income, median wealth, and median non-housing wealth, benchmark statistics are obtained from tabulations by the Congressional Budget Office [1993] based on the 1989 Survey of Consumer Finances and the 1990 Current Population Survey. The benchmark sample consists of households with heads between the ages of 35 to 44 . An identical subset of the Merrill Lynch sample is used for the comparison. For pensions, benchmark statistics are based on the authors' calculations, using the 1992 Survey of Consumer Finances. The benchmark sample is constructed to mirror the entire Merrill Lynch sample, rather than a restricted age group. All income and wealth figures are reported in 1994 dollars.

2. Refers to maximum educational attainment of household head.

3. Refers to total income for the benchmark sample, and total earnings from employment in the Merrill Lynch sample.

4. Refers to fraction of indicated subsample eligible for any kind of pension. 
Table 3: Probit Estimates for Retirement Education Offerings

\begin{tabular}{|c|c|c|c|c|c|}
\hline \multicolumn{2}{|c|}{ Variable } & \multirow{2}{*}{$\begin{array}{c}\text { Equation (1) } \\
\text { Availability } \\
\begin{array}{c}0.990 \\
(0.0839)\end{array}\end{array}$} & \multirow{2}{*}{$\begin{array}{c}\text { Equation (2) } \\
\text { Availability } \\
1.02 \\
(0.0859)\end{array}$} & \multirow{2}{*}{$\begin{array}{c}\begin{array}{c}\text { Equation (3) } \\
\text { Usage }\end{array} \\
0.397 \\
(0.134)\end{array}$} & \multirow{2}{*}{$\begin{array}{c}\begin{array}{c}\text { Equation (4) } \\
\text { Usage }\end{array} \\
0.389 \\
(0.138)\end{array}$} \\
\hline Pensions & RE40IK & & & & \\
\hline & ROPEN & $\begin{array}{c}0.698 \\
(0.126)\end{array}$ & $\begin{array}{c}0.720 \\
(0.127)\end{array}$ & $\begin{array}{c}-0.00715 \\
(0.183)\end{array}$ & $\begin{array}{c}-0.00058 \\
(0.185)\end{array}$ \\
\hline & R2PENS & $\begin{array}{l}-0.495 \\
(0.164)\end{array}$ & $\begin{array}{l}-0.508 \\
(0.165)\end{array}$ & $\begin{array}{l}0.0291 \\
(0.222)\end{array}$ & $\begin{array}{l}0.0220 \\
(0.223)\end{array}$ \\
\hline & SE401K & & $\begin{array}{c}-0.0473 \\
(0.0845)\end{array}$ & & $\begin{array}{c}0.133 \\
(0.121)\end{array}$ \\
\hline \multirow[t]{6}{*}{ Demographics } & MAR & $\begin{array}{l}-0.0845 \\
(0.0766)\end{array}$ & $\begin{array}{l}-0.0400 \\
(0.0852)\end{array}$ & $\begin{array}{c}0.172 \\
(0.104)\end{array}$ & $\begin{array}{c}0.116 \\
(0.116)\end{array}$ \\
\hline & FEMALE & $\begin{array}{c}0.280 \\
(0.0758)\end{array}$ & $\begin{array}{c}0.242 \\
(0.0787)\end{array}$ & $\begin{array}{l}-0.0875 \\
(0.105)\end{array}$ & $\begin{array}{l}-0.105 \\
(0.109)\end{array}$ \\
\hline & BLACK & $\begin{array}{c}0.505 \\
(0.148)\end{array}$ & $\begin{array}{c}0.477 \\
(0.150)\end{array}$ & $\begin{array}{l}0.0437 \\
(0.169)\end{array}$ & $\begin{array}{l}0.0160 \\
(0.171)\end{array}$ \\
\hline & OTHER & $\begin{array}{c}0.440 \\
(0.147)\end{array}$ & $\begin{array}{c}0.426 \\
(0.147)\end{array}$ & $\begin{array}{l}-0.216 \\
(0.186)\end{array}$ & $\begin{array}{l}-0.209 \\
(0.186)\end{array}$ \\
\hline & RED & $\begin{array}{c}0.0406 \\
(0.0241)\end{array}$ & $\begin{array}{c}0.0545 \\
(0.0256)\end{array}$ & $\begin{array}{c}0.0471 \\
(0.0345)\end{array}$ & $\begin{array}{c}0.0560 \\
(0.0363)\end{array}$ \\
\hline & RAGE/100 & $\begin{array}{c}0.433 \\
(0.652)\end{array}$ & $\begin{array}{c}0.465 \\
(0.652)\end{array}$ & $\begin{array}{l}-0.0246 \\
(0.918)\end{array}$ & $\begin{array}{l}0.0583 \\
(0.921)\end{array}$ \\
\hline \multirow[t]{3}{*}{ Employment } & LREARN & $\begin{array}{c}0.111 \\
(0.0562)\end{array}$ & $\begin{array}{c}0.118 \\
(0.0575)\end{array}$ & $\begin{array}{l}-0.0581 \\
(0.0985)\end{array}$ & $\begin{array}{l}-0.0430 \\
(0.0996)\end{array}$ \\
\hline & RSE & $\begin{array}{l}-0.661 \\
(0.097)\end{array}$ & $\begin{array}{c}-0.673 \\
(0.0981)\end{array}$ & $\begin{array}{c}0.315 \\
(0.190)\end{array}$ & $\begin{array}{c}0.325 \\
(0.192)\end{array}$ \\
\hline & RPART & $\begin{array}{l}-0.207 \\
(0.128)\end{array}$ & $\begin{array}{c}-0.201 \\
(0.129)\end{array}$ & $\begin{array}{c}-0.287 \\
(0.194)\end{array}$ & $\begin{array}{l}-0.298 \\
(0.196)\end{array}$ \\
\hline \multirow[t]{3}{*}{ Other } & Constant & $\begin{array}{c}-1.97 \\
(0.608)\end{array}$ & $\begin{array}{c}-1.82 \\
(0.623)\end{array}$ & $\begin{array}{l}0.788 \\
(1.02)\end{array}$ & $\begin{array}{l}0.852 \\
(1.02)\end{array}$ \\
\hline & TSCORE & & $\begin{array}{l}-0.647 \\
(0.299)\end{array}$ & & $\begin{array}{c}-0.237 \\
(0.427)\end{array}$ \\
\hline & PARSAVE & & $\begin{array}{l}0.0286 \\
(.0216)\end{array}$ & & $\begin{array}{l}-0.0361 \\
(0.0301)\end{array}$ \\
\hline $\begin{array}{l}\text { Observations } \\
\text { Log likelihood }\end{array}$ & & $\begin{array}{c}1594 \\
-897.3\end{array}$ & $\begin{array}{l}1594 \\
-893.7\end{array}$ & $\begin{array}{c}863 \\
-456.5\end{array}$ & $\begin{array}{c}863 \\
-455.1\end{array}$ \\
\hline
\end{tabular}


Table 4: Primary Source of Advice and Information on Retirement Planning

\begin{tabular}{|l|c|c|c|c|}
\hline \multirow{2}{*}{$\begin{array}{l}\text { Primary source of advice and } \\
\text { information }\end{array}$} & \multicolumn{2}{|c|}{ Raw Data } & \multicolumn{2}{c|}{$\begin{array}{c}\text { Fitted, based on } \\
\text { multinomial logit }\end{array}$} \\
\cline { 2 - 5 } & $\begin{array}{c}\text { Education not } \\
\text { offered }\end{array}$ & $\begin{array}{c}\text { Education } \\
\text { offered }\end{array}$ & $\begin{array}{c}\text { Education not } \\
\text { offered }\end{array}$ & $\begin{array}{c}\text { Education } \\
\text { offered }\end{array}$ \\
\hline Employer & $7.4 \%$ & $27.0 \%$ & $8.2 \%$ & $24.9 \%$ \\
Financial professional & $24.3 \%$ & $23.3 \%$ & $25.1 \%$ & $23.0 \%$ \\
Parents, friends, relatives & $24.6 \%$ & $19.2 \%$ & $22.4 \%$ & $21.6 \%$ \\
Print media & $18.2 \%$ & $15.4 \%$ & $20.2 \%$ & $14.2 \%$ \\
Own judgement & $14.5 \%$ & $9.3 \%$ & $14.4 \%$ & $9.5 \%$ \\
Other & $11.0 \%$ & $5.7 \%$ & $9.7 \%$ & $6.8 \%$ \\
\hline Total all sources & $100.0 \%$ & $100.0 \%$ & $100.0 \%$ & $100.0 \%$ \\
\hline
\end{tabular}


Table 5: Probit Estimates for Primary Sources of Advice and Information Concerning Retirement Planning

\begin{tabular}{|c|c|c|c|c|c|c|c|}
\hline \multicolumn{2}{|c|}{ Variable } & \multirow{2}{*}{$\begin{array}{c}\text { Employer } \\
\begin{array}{c}0.743 \\
(0.0877)\end{array}\end{array}$} & \multirow{2}{*}{$\begin{array}{c}\begin{array}{c}\text { Financial } \\
\text { Pro. }\end{array} \\
\begin{array}{c}-0.0681 \\
(0.0750)\end{array}\end{array}$} & \multirow{2}{*}{$\begin{array}{c}\begin{array}{c}\text { Parents } \\
\text { etc. }\end{array} \\
\begin{array}{c}-0.0308 \\
(0.0776)\end{array}\end{array}$} & \multirow{2}{*}{$\begin{array}{c}\begin{array}{c}\text { Print } \\
\text { media }\end{array} \\
\begin{array}{c}-0.250 \\
(0.0829)\end{array}\end{array}$} & \multirow{2}{*}{$\begin{array}{c}\begin{array}{c}\text { Own } \\
\text { judgement }\end{array} \\
\begin{array}{c}-0.244 \\
(0.0901)\end{array}\end{array}$} & \multirow{2}{*}{$\begin{array}{c}\text { Other } \\
\begin{array}{c}-0.200 \\
(0.1012)\end{array}\end{array}$} \\
\hline Education & OEBRE & & & & & & \\
\hline Pensions & RE401K & $\begin{array}{c}0.045 \\
(0.088)\end{array}$ & $\begin{array}{c}0.017 \\
(0.078)\end{array}$ & $\begin{array}{c}-0.198 \\
(0.081)\end{array}$ & $\begin{array}{c}0.310 \\
(0.088)\end{array}$ & $\begin{array}{c}-0.062 \\
(0.094)\end{array}$ & $\begin{array}{l}-0.189 \\
(0.106)\end{array}$ \\
\hline & ROPEN & $\begin{array}{c}0.112 \\
(0.091)\end{array}$ & $\begin{array}{c}-0.002 \\
(0.085)\end{array}$ & $\begin{array}{c}-0.279 \\
(0.094)\end{array}$ & $\begin{array}{c}0.129 \\
(0.091)\end{array}$ & $\begin{array}{c}0.088 \\
(0.102)\end{array}$ & $\begin{array}{c}-0.043 \\
(0.121)\end{array}$ \\
\hline & SE401K & $\begin{array}{c}-0.128 \\
(0.100)\end{array}$ & $\begin{array}{c}0.161 \\
(0.089)\end{array}$ & $\begin{array}{c}-0.071 \\
(0.092)\end{array}$ & $\begin{array}{c}-0.062 \\
(0.098)\end{array}$ & $\begin{array}{c}0.095 \\
(0.108)\end{array}$ & $\begin{array}{c}0.053 \\
(0.121)\end{array}$ \\
\hline & SOPEN & $\begin{array}{c}-0.038 \\
(0.115)\end{array}$ & $\begin{array}{c}0.107 \\
(0.099)\end{array}$ & $\begin{array}{c}-0.064 \\
(0.107)\end{array}$ & $\begin{array}{c}0.002 \\
(0.109)\end{array}$ & $\begin{array}{c}-0.003 \\
(0.124)\end{array}$ & $\begin{array}{c}-0.046 \\
(0.141)\end{array}$ \\
\hline \multirow[t]{8}{*}{ Demographics } & MAR & $\begin{array}{c}0.057 \\
(0.342)\end{array}$ & $\begin{array}{c}-0.456 \\
(0.295)\end{array}$ & $\begin{array}{c}0.282 \\
(0.335)\end{array}$ & $\begin{array}{c}-0.038 \\
(0.318)\end{array}$ & $\begin{array}{c}0.031 \\
(0.345)\end{array}$ & $\begin{array}{c}0.582 \\
(0.506)\end{array}$ \\
\hline & FEMALE & $\begin{array}{c}0.247 \\
(0.087)\end{array}$ & $\begin{array}{c}0.155 \\
(0.078)\end{array}$ & $\begin{array}{c}0.133 \\
(0.081)\end{array}$ & $\begin{array}{c}-0.234 \\
(0.086)\end{array}$ & $\begin{array}{c}-0.423 \\
(0.096)\end{array}$ & $\begin{array}{c}-0.011 \\
(0.105)\end{array}$ \\
\hline & BLACK & $\begin{array}{c}0.069 \\
(0.140)\end{array}$ & $\begin{array}{c}-0.097 \\
(0.141)\end{array}$ & $\begin{array}{c}-0.006 \\
(0.138)\end{array}$ & $\begin{array}{c}-0.292 \\
(0.171)\end{array}$ & $\begin{array}{c}0.303 \\
(0.153)\end{array}$ & $\begin{array}{c}-0.029 \\
(0.181)\end{array}$ \\
\hline & OTHER & $\begin{array}{c}0.025 \\
(0.155)\end{array}$ & $\begin{array}{c}-0.269 \\
(0.149)\end{array}$ & $\begin{array}{c}0.047 \\
(0.137)\end{array}$ & $\begin{array}{c}-0.072 \\
(0.154)\end{array}$ & $\begin{array}{c}0.237 \\
(0.148)\end{array}$ & $\begin{array}{c}0.023 \\
(0.176)\end{array}$ \\
\hline & RED & $\begin{array}{c}-0.087 \\
(0.029)\end{array}$ & $\begin{array}{c}0.054 \\
(0.025)\end{array}$ & $\begin{array}{c}-0.031 \\
(0.026)\end{array}$ & $\begin{array}{c}0.140 \\
(0.028)\end{array}$ & $\begin{array}{c}-0.020 \\
(0.030)\end{array}$ & $\begin{array}{c}-0.108 \\
(0.034)\end{array}$ \\
\hline & SED & $\begin{array}{c}-0.062 \\
(0.033)\end{array}$ & $\begin{array}{c}0.061 \\
(0.029)\end{array}$ & $\begin{array}{c}0.022 \\
(0.030)\end{array}$ & $\begin{array}{c}-0.030 \\
(0.032)\end{array}$ & $\begin{array}{c}-0.043 \\
(0.035)\end{array}$ & $\begin{array}{c}0.012 \\
(0.040)\end{array}$ \\
\hline & RAGE/100 & $\begin{array}{c}0.688 \\
(0.887)\end{array}$ & $\begin{array}{c}0.487 \\
(0.812)\end{array}$ & $\begin{array}{c}-3.286 \\
(0.817)\end{array}$ & $\begin{array}{c}2.216 \\
(0.896)\end{array}$ & $\begin{array}{c}-0.017 \\
(0.961)\end{array}$ & $\begin{array}{l}0.384 \\
(1.04)\end{array}$ \\
\hline & SAGE $/ 100$ & $\begin{array}{c}0.813 \\
(0.919)\end{array}$ & $\begin{array}{c}0.522 \\
(0.808)\end{array}$ & $\begin{array}{c}0.336 \\
(0.829)\end{array}$ & $\begin{array}{c}1.67 \\
(0.901)\end{array}$ & $\begin{array}{c}0.605 \\
(0.970)\end{array}$ & $\begin{array}{l}-1.03 \\
(1.07)\end{array}$ \\
\hline \multirow[t]{5}{*}{ Employment } & LREARN & $\begin{array}{c}0.0142 \\
(0.0256)\end{array}$ & $\begin{array}{c}0.0187 \\
(0.0200)\end{array}$ & $\begin{array}{c}-0.0160 \\
(0.0195)\end{array}$ & $\begin{array}{c}-0.0269 \\
(0.0216)\end{array}$ & $\begin{array}{c}0.0227 \\
(0.0228)\end{array}$ & $\begin{array}{c}-0.0141 \\
(0.0241)\end{array}$ \\
\hline & LSEARN & $\begin{array}{c}0.0303 \\
(0.0319)\end{array}$ & $\begin{array}{c}0.0233 \\
(0.0270)\end{array}$ & $\begin{array}{c}-0.0402 \\
(0.0313)\end{array}$ & $\begin{array}{c}0.0186 \\
(0.0295)\end{array}$ & $\begin{array}{c}0.0084 \\
(0.0316)\end{array}$ & $\begin{array}{c}-0.0804 \\
(0.0461)\end{array}$ \\
\hline & RSE & $\begin{array}{c}-0.515 \\
(0.141)\end{array}$ & $\begin{array}{c}0.071 \\
(0.098)\end{array}$ & $\begin{array}{c}0.041 \\
(0.101)\end{array}$ & $\begin{array}{c}0.042 \\
(0.108)\end{array}$ & $\begin{array}{c}0.064 \\
(0.115)\end{array}$ & $\begin{array}{c}0.171 \\
(0.126)\end{array}$ \\
\hline & SSE & $\begin{array}{l}-0.220 \\
(0.154)\end{array}$ & $\begin{array}{c}0.198 \\
(0.122)\end{array}$ & $\begin{array}{c}-0.135 \\
(0.130)\end{array}$ & $\begin{array}{c}0.033 \\
(0.134)\end{array}$ & $\begin{array}{c}0.149 \\
(0.148)\end{array}$ & $\begin{array}{c}-0.101 \\
(0.175)\end{array}$ \\
\hline & RPART & $\begin{array}{c}-0.239 \\
(0.146)\end{array}$ & $\begin{array}{c}-0.116 \\
(0.128)\end{array}$ & $\begin{array}{c}0.115 \\
(0.126)\end{array}$ & $\begin{array}{c}-0.045 \\
(0.148)\end{array}$ & $\begin{array}{c}0.097 \\
(0.159)\end{array}$ & $\begin{array}{c}0.263 \\
(0.156)\end{array}$ \\
\hline
\end{tabular}




\begin{tabular}{|c|c|c|c|c|c|c|}
\hline Variable & Employer & $\begin{array}{c}\text { Financial } \\
\text { Pro. }\end{array}$ & $\begin{array}{l}\text { Parents } \\
\text { etc. }\end{array}$ & $\begin{array}{c}\text { Print } \\
\text { media }\end{array}$ & $\begin{array}{c}\text { Own } \\
\text { judgement }\end{array}$ & Other \\
\hline SPART & $\begin{array}{c}-0.127 \\
(0.172)\end{array}$ & $\begin{array}{c}0.040 \\
(0.151)\end{array}$ & $\begin{array}{c}0.248 \\
(0.150)\end{array}$ & $\begin{array}{c}-0.289 \\
(0.168)\end{array}$ & $\begin{array}{c}0.086 \\
(0.169)\end{array}$ & $\begin{array}{l}-0.077 \\
(0.215)\end{array}$ \\
\hline RNOWORK & $\begin{array}{l}-0.241 \\
(0.210)\end{array}$ & $\begin{array}{l}-0.041 \\
(0.173)\end{array}$ & $\begin{array}{l}-0.032 \\
(0.171)\end{array}$ & $\begin{array}{c}0.111 \\
(0.189)\end{array}$ & $\begin{array}{c}0.252 \\
(0.186)\end{array}$ & $\begin{array}{l}-0.049 \\
(0.206)\end{array}$ \\
\hline SNOWORK & $\begin{array}{c}-0.006 \\
(0.293)\end{array}$ & $\begin{array}{c}0.363 \\
(0.256)\end{array}$ & $\begin{array}{c}-0.389 \\
(0.301)\end{array}$ & $\begin{array}{c}0.028 \\
(0.279)\end{array}$ & $\begin{array}{c}0.185 \\
(0.300)\end{array}$ & $\begin{array}{l}-0.574 \\
(0.483)\end{array}$ \\
\hline Constant & $\begin{array}{c}-1.91 \\
(0.422)\end{array}$ & $\begin{array}{c}-1.64 \\
(0.351)\end{array}$ & $\begin{array}{c}0.76 \\
(0.36)\end{array}$ & $\begin{array}{l}-1.40 \\
(0.39)\end{array}$ & $\begin{array}{l}-1.36 \\
(0.41)\end{array}$ & $\begin{array}{l}-0.35 \\
(0.46)\end{array}$ \\
\hline $\begin{array}{l}\text { Observations } \\
\text { Log Likelihood }\end{array}$ & $\begin{array}{r}1,819 \\
-738.9\end{array}$ & $\begin{array}{r}1,819 \\
-972.7\end{array}$ & $\begin{array}{r}1,819 \\
-918.9\end{array}$ & $\begin{array}{r}1,819 \\
-782.8\end{array}$ & $\begin{array}{r}1,819 \\
-635.6\end{array}$ & $\begin{array}{r}1,819 \\
-497.4\end{array}$ \\
\hline
\end{tabular}


Table 6: Median Regressions for Various Measures of Wealth and Saving: The Availability of Retirement Education

\begin{tabular}{|c|c|c|c|c|c|}
\hline \multicolumn{2}{|c|}{ Variable } & \multirow{2}{*}{$\begin{array}{c}\begin{array}{c}\text { Total } \\
\text { Wealth }\end{array} \\
\begin{array}{c}1793 \\
(6399)\end{array}\end{array}$} & \multirow{2}{*}{$\begin{array}{c}\begin{array}{c}\text { Retirement } \\
\text { Wealth }\end{array} \\
2488 \\
(1016)\end{array}$} & \multirow{2}{*}{$\begin{array}{c}\begin{array}{c}\text { Total saving } \\
\text { rate }\end{array} \\
\begin{array}{c}1.650 \\
(0.462)\end{array}\end{array}$} & \multirow{2}{*}{$\begin{array}{c}\begin{array}{c}\text { Retirement } \\
\text { saving rate }\end{array} \\
\begin{array}{c}0.922 \\
(0.354)\end{array}\end{array}$} \\
\hline Education & OEBRE & & & & \\
\hline Pensions & RE401(k) & $\begin{array}{l}24286 \\
(6766)\end{array}$ & $\begin{array}{l}6550 \\
(1069)\end{array}$ & $\begin{array}{c}1.470 \\
(0.491)\end{array}$ & $\begin{array}{c}1.963 \\
(0.374)\end{array}$ \\
\hline & ROPEN & $\begin{array}{c}4886 \\
(7267)\end{array}$ & $\begin{array}{c}6472 \\
(1145)\end{array}$ & $\begin{array}{c}0.330 \\
(0.523)\end{array}$ & $\begin{array}{c}0.408 \\
(0.397)\end{array}$ \\
\hline & SE401(k) & $\begin{array}{l}13702 \\
(7697)\end{array}$ & $\begin{array}{c}3122 \\
(1206)\end{array}$ & $\begin{array}{c}0.856 \\
(0.558)\end{array}$ & $\begin{array}{c}0.539 \\
(0.424)\end{array}$ \\
\hline & SOPEN & $\begin{array}{c}1760 \\
(8902)\end{array}$ & $\begin{array}{c}2058 \\
(1376)\end{array}$ & $\begin{array}{c}0.108 \\
(0.643)\end{array}$ & $\begin{array}{c}0.237 \\
(0.491)\end{array}$ \\
\hline Demographics & MAR & $\begin{array}{l}-68282 \\
(25320)\end{array}$ & $\begin{array}{l}-14255 \\
(3997)\end{array}$ & $\begin{array}{c}2.254 \\
(1.840)\end{array}$ & $\begin{array}{c}-0.104 \\
(1.400)\end{array}$ \\
\hline & FEMALE & $\begin{array}{l}-8751 \\
(6803)\end{array}$ & $\begin{array}{l}-4534 \\
(1069)\end{array}$ & $\begin{array}{l}-0.110 \\
(0.491)\end{array}$ & $\begin{array}{c}-0.215 \\
(0.375)\end{array}$ \\
\hline & BLACK & $\begin{array}{c}-14396 \\
(11662)\end{array}$ & $\begin{array}{l}-1210 \\
(1863)\end{array}$ & $\begin{array}{c}-0.132 \\
(0.853)\end{array}$ & $\begin{array}{r}-0.0865 \\
(0.628)\end{array}$ \\
\hline & OTHER & $\begin{array}{c}14667 \\
(11613)\end{array}$ & $\begin{array}{c}36 \\
(1780)\end{array}$ & $\begin{array}{c}-0.828 \\
(0.839)\end{array}$ & $\begin{array}{c}-0.718 \\
(0.632)\end{array}$ \\
\hline & RED & $\begin{array}{c}5888 \\
(2264)\end{array}$ & $\begin{array}{l}1202 \\
(352)\end{array}$ & $\begin{array}{c}0.425 \\
(0.165)\end{array}$ & $\begin{array}{c}0.199 \\
(0.125)\end{array}$ \\
\hline & SED & $\begin{array}{l}12806 \\
(2501)\end{array}$ & $\begin{array}{l}1582 \\
(389)\end{array}$ & $\begin{array}{c}-0.327 \\
(0.182)\end{array}$ & $\begin{array}{r}-0.0244 \\
(0.138)\end{array}$ \\
\hline & RAGE & $\begin{array}{l}3215 \\
(682)\end{array}$ & $\begin{array}{c}490 \\
(106)\end{array}$ & $\begin{array}{c}-0.202 \\
(0.0497)\end{array}$ & $\begin{array}{c}-0.0778 \\
(0.0381)\end{array}$ \\
\hline & SAGE & $\begin{array}{l}2637 \\
(690)\end{array}$ & $\begin{array}{c}442 \\
(108)\end{array}$ & $\begin{array}{c}0.0931 \\
(0.0497)\end{array}$ & $\begin{array}{c}0.0668 \\
(0.0382)\end{array}$ \\
\hline Employment & LREARN & $\begin{array}{c}3025 \\
(1670)\end{array}$ & $\begin{array}{c}498 \\
(262)\end{array}$ & $\begin{array}{c}0.122 \\
(0.123)\end{array}$ & $\begin{array}{c}-0.0320 \\
(0.0930)\end{array}$ \\
\hline & LSEARN & $\begin{array}{c}7595 \\
(2346)\end{array}$ & $\begin{array}{l}1555 \\
(367)\end{array}$ & $\begin{array}{c}0.0977 \\
(0.170)\end{array}$ & $\begin{array}{c}0.181 \\
(0.129)\end{array}$ \\
\hline & RSE & $\begin{array}{l}71964 \\
(8813)\end{array}$ & $\begin{array}{c}-57 \\
(1326)\end{array}$ & $\begin{array}{c}-0.526 \\
(0.645)\end{array}$ & $\begin{array}{c}-0.985 \\
(0.494)\end{array}$ \\
\hline & SSE & $\begin{array}{c}67420 \\
(11022)\end{array}$ & $\begin{array}{c}-243 \\
(1658)\end{array}$ & $\begin{array}{l}-1.165 \\
(0.796)\end{array}$ & $\begin{array}{c}-0.850 \\
(0.606)\end{array}$ \\
\hline & RPART & $\begin{array}{c}3796 \\
(11010)\end{array}$ & $\begin{array}{c}-941 \\
(1727)\end{array}$ & $\begin{array}{l}-2.522 \\
(0.796)\end{array}$ & $\begin{array}{c}-1.267 \\
(0.609)\end{array}$ \\
\hline
\end{tabular}




\begin{tabular}{|c|c|c|c|c|c|}
\hline & Variable & $\begin{array}{c}\text { Total } \\
\text { Wealth }\end{array}$ & $\begin{array}{c}\text { Retirement } \\
\text { Wealth }\end{array}$ & $\begin{array}{c}\text { Total saving } \\
\text { rate }\end{array}$ & Retirement \\
\hline & SPART & $\begin{array}{c}15247 \\
(12511)\end{array}$ & $\begin{array}{c}-3043 \\
(1965)\end{array}$ & $\begin{array}{l}-3.307 \\
(0.904)\end{array}$ & $\begin{array}{c}-2.744 \\
(0.680)\end{array}$ \\
\hline & RNOWORK & $\begin{array}{c}16310 \\
(13957)\end{array}$ & $\begin{array}{c}3134 \\
(2222)\end{array}$ & $\begin{array}{c}-0.660 \\
(1.034)\end{array}$ & $\begin{array}{c}-1.029 \\
(0.780)\end{array}$ \\
\hline & SNOWORK & $\begin{array}{c}69747 \\
(22433)\end{array}$ & $\begin{array}{c}9271 \\
(3500)\end{array}$ & $\begin{array}{l}-1.704 \\
(1.624)\end{array}$ & $\begin{array}{c}0.258 \\
(1.234)\end{array}$ \\
\hline Other & Constant & $\begin{array}{l}-307450 \\
(32432)\end{array}$ & $\begin{array}{l}-50253 \\
(5059)\end{array}$ & $\begin{array}{r}-57.66 \\
(4.39)\end{array}$ & $\begin{array}{l}-34.38 \\
(3.32)\end{array}$ \\
\hline & TSCORE & $\begin{array}{l}60874 \\
(24611)\end{array}$ & $\begin{array}{l}15222 \\
(3846)\end{array}$ & $\begin{array}{c}1.866 \\
(1.783)\end{array}$ & $\begin{array}{c}1.360 \\
(1.355)\end{array}$ \\
\hline & PARSAVE & $\begin{array}{c}8075 \\
(1743)\end{array}$ & $\begin{array}{c}826 \\
(273)\end{array}$ & $\begin{array}{c}0.199 \\
(0.127)\end{array}$ & $\begin{array}{c}0.225 \\
(0.096)\end{array}$ \\
\hline & LOGTW & & & $\begin{array}{c}5.029 \\
(0.341)\end{array}$ & $\begin{array}{c}2.833 \\
(0.259)\end{array}$ \\
\hline Observ & & 1,523 & 1,615 & 1,500 & 1,493 \\
\hline
\end{tabular}


Table 7: Median Regressions for Various Measures of Wealth and Saving: Usage of Retirement Education

\begin{tabular}{|c|c|c|c|c|c|}
\hline \multicolumn{2}{|c|}{ Variable } & \multirow{2}{*}{$\begin{array}{c}\begin{array}{c}\text { Total } \\
\text { Wealth }\end{array} \\
\begin{array}{c}1384 \\
(6378)\end{array}\end{array}$} & \multirow{2}{*}{$\begin{array}{c}\begin{array}{c}\text { Retirement } \\
\text { Wealth }\end{array} \\
2176 \\
(991)\end{array}$} & \multirow{2}{*}{$\begin{array}{c}\begin{array}{c}\text { Total saving } \\
\text { rate }\end{array} \\
2.182 \\
(0.486)\end{array}$} & \multirow{2}{*}{$\begin{array}{c}\begin{array}{c}\text { Retirement } \\
\text { saving rate }\end{array} \\
\begin{array}{c}1.829 \\
(0.282)\end{array}\end{array}$} \\
\hline Education & UEBRE & & & & \\
\hline Pensions & RE401(k) & $\begin{array}{l}24567 \\
(6827)\end{array}$ & $\begin{array}{c}6695 \\
(1049)\end{array}$ & $\begin{array}{c}1.421 \\
(0.522)\end{array}$ & $\begin{array}{c}1.580 \\
(0.304)\end{array}$ \\
\hline & ROPEN & $\begin{array}{c}5092 \\
(7371)\end{array}$ & $\begin{array}{c}6982 \\
(1133)\end{array}$ & $\begin{array}{c}0.313 \\
(0.559)\end{array}$ & $\begin{array}{c}0.503 \\
(0.324)\end{array}$ \\
\hline & SE401(k) & $\begin{array}{r}14154 \\
(7854)\end{array}$ & $\begin{array}{c}2762 \\
(1193)\end{array}$ & $\begin{array}{c}0.788 \\
(0.596)\end{array}$ & $\begin{array}{c}0.923 \\
(0.348)\end{array}$ \\
\hline & SOPEN & $\begin{array}{c}1417 \\
(9085)\end{array}$ & $\begin{array}{c}1847 \\
(1369)\end{array}$ & $\begin{array}{c}0.170 \\
(0.690)\end{array}$ & $\begin{array}{c}0.272 \\
(0.400)\end{array}$ \\
\hline Demographics & MAR & $\begin{array}{l}-67542 \\
(26325)\end{array}$ & $\begin{array}{l}-13408 \\
(3965)\end{array}$ & $\begin{array}{c}3.025 \\
(1.973)\end{array}$ & $\begin{array}{c}-1.008 \\
(1.159)\end{array}$ \\
\hline & FEMALE & $\begin{array}{c}-8875 \\
(6925)\end{array}$ & $\begin{array}{c}-4078 \\
(1058)\end{array}$ & $\begin{array}{c}-0.348 \\
(0.526)\end{array}$ & $\begin{array}{c}-0.396 \\
(0.308)\end{array}$ \\
\hline & BLACK & $\begin{array}{c}-14069 \\
(11806)\end{array}$ & $\begin{array}{l}-1061 \\
(1853)\end{array}$ & $\begin{array}{c}0.067 \\
(0.911)\end{array}$ & $\begin{array}{c}-0.301 \\
(0.516)\end{array}$ \\
\hline & OTHER & $\begin{array}{c}17939 \\
(11847)\end{array}$ & $\begin{array}{c}-416 \\
(1780)\end{array}$ & $\begin{array}{c}-0.766 \\
(0.892)\end{array}$ & $\begin{array}{l}-0.272 \\
(0.519)\end{array}$ \\
\hline & RED & $\begin{array}{c}5681 \\
(2312)\end{array}$ & $\begin{array}{l}1245 \\
(351)\end{array}$ & $\begin{array}{c}0.491 \\
(0.176)\end{array}$ & $\begin{array}{c}0.218 \\
(0.102)\end{array}$ \\
\hline & SED & $\begin{array}{l}12802 \\
(2555)\end{array}$ & $\begin{array}{l}1448 \\
(387)\end{array}$ & $\begin{array}{l}-0.397 \\
(0.194)\end{array}$ & $\begin{array}{l}-0.058 \\
(0.113)\end{array}$ \\
\hline & RAGE & $\begin{array}{l}3205 \\
(694)\end{array}$ & $\begin{array}{c}485 \\
(106)\end{array}$ & $\begin{array}{c}-0.212 \\
(0.053)\end{array}$ & $\begin{array}{c}-0.0699 \\
(0.0312)\end{array}$ \\
\hline & SAGE & $\begin{array}{l}2669 \\
(704)\end{array}$ & $\begin{array}{c}429 \\
(107)\end{array}$ & $\begin{array}{c}0.0988 \\
(0.0534)\end{array}$ & $\begin{array}{c}0.0731 \\
(0.0314)\end{array}$ \\
\hline Employment & LREARN & $\begin{array}{c}3011 \\
(1707)\end{array}$ & $\begin{array}{c}505 \\
(258)\end{array}$ & $\begin{array}{c}0.161 \\
(0.131)\end{array}$ & $\begin{array}{c}-0.0604 \\
(0.0755)\end{array}$ \\
\hline & LSEARN & $\begin{array}{c}7554 \\
(2440)\end{array}$ & $\begin{array}{l}1519 \\
(364)\end{array}$ & $\begin{array}{c}0.064 \\
(0.182)\end{array}$ & $\begin{array}{c}0.242 \\
(0.107)\end{array}$ \\
\hline & RSE & $\begin{array}{l}71436 \\
(8933)\end{array}$ & $\begin{array}{c}-682 \\
(1309)\end{array}$ & $\begin{array}{c}-0.376 \\
(0.689)\end{array}$ & $\begin{array}{c}-0.890 \\
(0.402)\end{array}$ \\
\hline & SSE & $\begin{array}{c}67554 \\
(11218)\end{array}$ & $\begin{array}{c}-322 \\
(1643)\end{array}$ & $\begin{array}{c}-1.553 \\
(0.854)\end{array}$ & $\begin{array}{l}-0.766 \\
(0.497)\end{array}$ \\
\hline & RPART & $\begin{array}{c}4357 \\
(11243)\end{array}$ & $\begin{array}{c}-874 \\
(1717)\end{array}$ & $\begin{array}{c}-2.559 \\
(0.854)\end{array}$ & $\begin{array}{l}-1.351 \\
(0.499)\end{array}$ \\
\hline
\end{tabular}




\begin{tabular}{|c|c|c|c|c|c|}
\hline & Variable & $\begin{array}{c}\text { Total } \\
\text { Wealth }\end{array}$ & $\begin{array}{c}\text { Retirement } \\
\text { Wealth }\end{array}$ & $\begin{array}{c}\text { Total saving } \\
\text { rate }\end{array}$ & $\begin{array}{l}\text { Retirement } \\
\text { saving rate }\end{array}$ \\
\hline & SPART & $\begin{array}{c}14603 \\
(12775)\end{array}$ & $\begin{array}{l}-2869 \\
(1953)\end{array}$ & $\begin{array}{c}-3.658 \\
(0.962)\end{array}$ & $\begin{array}{l}-1.963 \\
(0.560)\end{array}$ \\
\hline & RNOWORK & $\begin{array}{c}15458 \\
(14322)\end{array}$ & $\begin{array}{r}2906 \\
(2178)\end{array}$ & $\begin{array}{c}-0.664 \\
(1.102)\end{array}$ & $\begin{array}{l}-1.007 \\
(0.627)\end{array}$ \\
\hline & SNOWORK & $\begin{array}{c}69846 \\
(23413)\end{array}$ & $\begin{array}{c}9519 \\
(3470)\end{array}$ & $\begin{array}{l}-2.346 \\
(1.741)\end{array}$ & $\begin{array}{c}1.040 \\
(1.028)\end{array}$ \\
\hline Other & Constant & $\begin{array}{l}-306877 \\
(33127)\end{array}$ & $\begin{array}{l}-49684 \\
(5021)\end{array}$ & $\begin{array}{l}-60.52 \\
(4.70)\end{array}$ & $\begin{array}{l}-35.7 \\
(2.73)\end{array}$ \\
\hline & TSCORE & $\begin{array}{c}60100 \\
(25138)\end{array}$ & $\begin{array}{l}15332 \\
(3803)\end{array}$ & $\begin{array}{c}1.294 \\
(1.910)\end{array}$ & $\begin{array}{c}1.103 \\
(1.118)\end{array}$ \\
\hline & PARSAVE & $\begin{array}{c}8088 \\
(1778)\end{array}$ & $\begin{array}{c}846 \\
(272)\end{array}$ & $\begin{array}{c}0.262 \\
(0.136)\end{array}$ & $\begin{array}{c}0.279 \\
(0.079)\end{array}$ \\
\hline & LOGTW & & & $\begin{array}{c}5.242 \\
(0.365)\end{array}$ & $\begin{array}{l}2.917 \\
(0.213)\end{array}$ \\
\hline Obser & & 1,523 & 1,615 & 1,500 & 1,493 \\
\hline
\end{tabular}




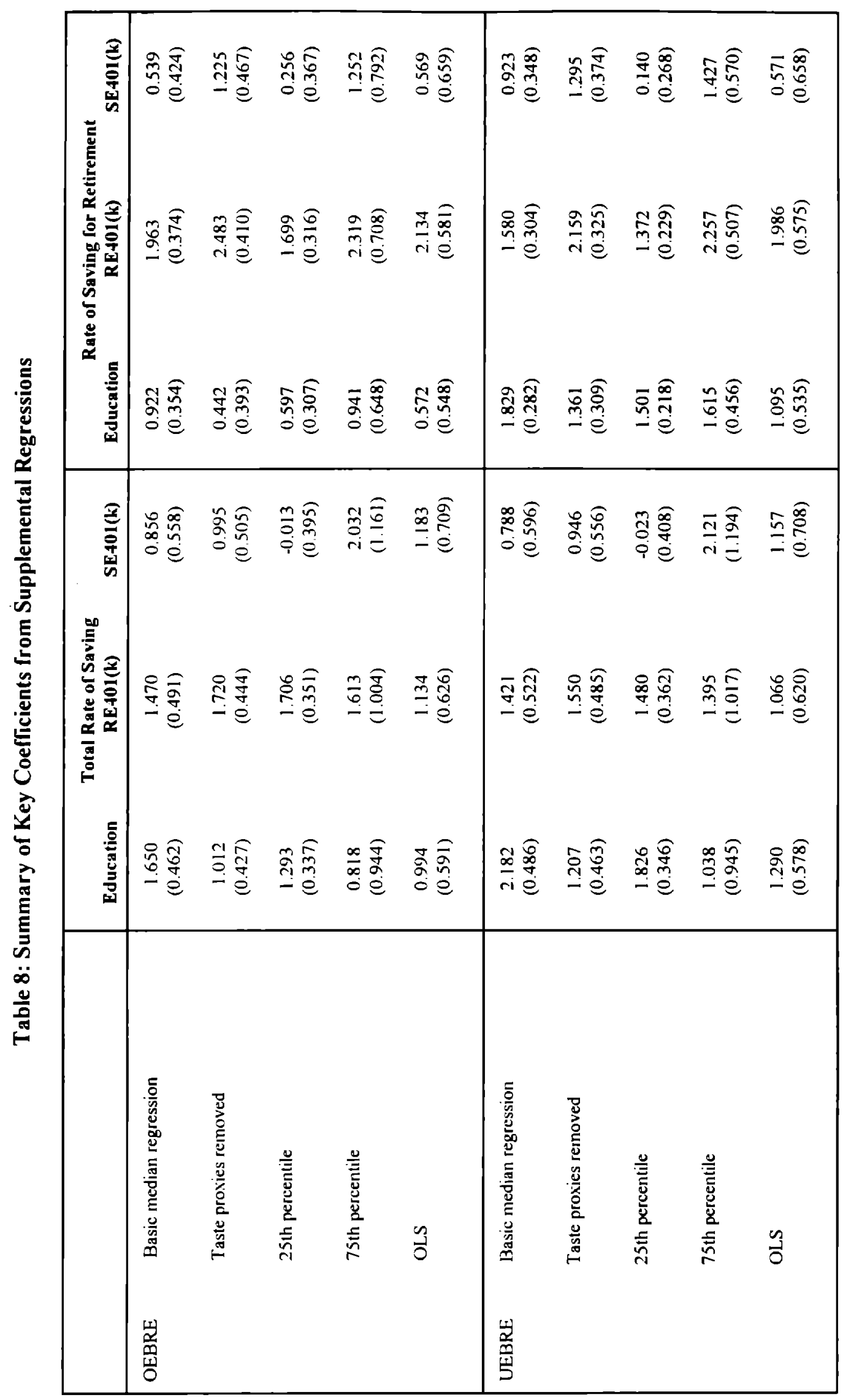


Table 9: Respondent's 401(k) Activity

\begin{tabular}{|c|c|c|c|c|c|}
\hline \multicolumn{2}{|c|}{ Variable } & \multirow{2}{*}{$\begin{array}{c}\begin{array}{c}\text { Equation (1) } \\
\text { Participation }\end{array} \\
\begin{array}{c}0.406 \\
(0.117)\end{array}\end{array}$} & \multirow{2}{*}{$\begin{array}{l}\text { Equation (2) } \\
\text { Participation }\end{array}$} & \multirow{2}{*}{$\begin{array}{c}\begin{array}{c}\text { Equation (3) } \\
\text { Balances }\end{array} \\
2,508 \\
(1,436)\end{array}$} & \multirow{2}{*}{$\begin{array}{c}\text { Equation (4) } \\
\text { Balances }\end{array}$} \\
\hline Education & OEBRE & & & & \\
\hline & UEBRE & & $\begin{array}{c}0.717 \\
(0.108)\end{array}$ & & $\begin{array}{c}2,826 \\
(1,058)\end{array}$ \\
\hline \multirow[t]{3}{*}{ Pensions } & ROPEN & $\begin{array}{l}-0.167 \\
(0.122)\end{array}$ & $\begin{array}{l}-0.195 \\
(0.125)\end{array}$ & $\begin{array}{c}-462 \\
(1,420)\end{array}$ & $\begin{array}{c}-521 \\
(1,198)\end{array}$ \\
\hline & SE40IK & $\begin{array}{c}-0.0479 \\
(0.139)\end{array}$ & $\begin{array}{c}-0.0488 \\
(0.143)\end{array}$ & $\begin{array}{c}-477 \\
(1572)\end{array}$ & $\begin{array}{c}-469 \\
(1,321)\end{array}$ \\
\hline & SOPEN & $\begin{array}{c}0.157 \\
(0.169)\end{array}$ & $\begin{array}{c}0.150 \\
(0.173)\end{array}$ & $\begin{array}{c}481 \\
(1,898)\end{array}$ & $\begin{array}{c}744 \\
(1,594)\end{array}$ \\
\hline \multirow[t]{6}{*}{ Demographics } & MAR & $\begin{array}{l}-0.0429 \\
(0.203)\end{array}$ & $\begin{array}{l}-0.0391 \\
(0.206)\end{array}$ & $\begin{array}{c}1,009 \\
(2,408)\end{array}$ & $\begin{array}{c}1,358 \\
(2,037)\end{array}$ \\
\hline & FEMALE & $\begin{array}{c}0.0544 \\
(0.125)\end{array}$ & $\begin{array}{c}0.0714 \\
(0.128)\end{array}$ & $\begin{array}{c}-809 \\
(1,450)\end{array}$ & $\begin{array}{c}-303 \\
(1,215)\end{array}$ \\
\hline & BLACK & $\begin{array}{c}-0.309 \\
(0.189)\end{array}$ & $\begin{array}{c}-0.338 \\
(0.193)\end{array}$ & $\begin{array}{c}-1,572 \\
(2,414)\end{array}$ & $\begin{array}{l}-1,137 \\
(2,032)\end{array}$ \\
\hline & OTHER & $\begin{array}{l}0.0291 \\
(0.261)\end{array}$ & $\begin{array}{l}0.0443 \\
(0.263)\end{array}$ & $\begin{array}{c}1,851 \\
(2,814)\end{array}$ & $\begin{array}{c}1,986 \\
(2,361)\end{array}$ \\
\hline & RED & $\begin{array}{c}-0.0010 \\
(0.0405)\end{array}$ & $\begin{array}{l}0.00996 \\
(0.0414)\end{array}$ & $\begin{array}{c}247 \\
(483)\end{array}$ & $\begin{array}{c}84 \\
(405)\end{array}$ \\
\hline & RAGE & $\begin{array}{c}-0.0109 \\
(0.0102)\end{array}$ & $\begin{array}{c}-0.00951 \\
(0.01049)\end{array}$ & $\begin{array}{c}282 \\
(118)\end{array}$ & $\begin{array}{l}297 \\
(99)\end{array}$ \\
\hline \multirow[t]{3}{*}{ Employment } & LREARN & $\begin{array}{c}0.351 \\
(0.114)\end{array}$ & $\begin{array}{c}0.356 \\
(0.115)\end{array}$ & $\begin{array}{l}10,170 \\
(1,460)\end{array}$ & $\begin{array}{r}10,139 \\
(1,228)\end{array}$ \\
\hline & LSEARN & $\begin{array}{c}0.0235 \\
(0.0210)\end{array}$ & $\begin{array}{c}0.0221 \\
(0.0213)\end{array}$ & $\begin{array}{c}-30 \\
(244)\end{array}$ & $\begin{array}{c}-58 \\
(206)\end{array}$ \\
\hline & RPART & $\begin{array}{l}-0.173 \\
(0.216)\end{array}$ & $\begin{array}{l}-0.0939 \\
(0.219)\end{array}$ & $\begin{array}{c}5,867 \\
(2,839)\end{array}$ & $\begin{array}{c}6,560 \\
(2,370)\end{array}$ \\
\hline \multirow[t]{3}{*}{ Other } & Constant & $\begin{array}{l}-2.832 \\
(1.171)\end{array}$ & $\begin{array}{l}-3.089 \\
(1.188)\end{array}$ & $\begin{array}{r}-116,158 \\
(14,966)\end{array}$ & $\begin{array}{r}-117,740 \\
(12,623)\end{array}$ \\
\hline & TSCORE & $\begin{array}{c}0.139 \\
(0.470)\end{array}$ & $\begin{array}{c}0.312 \\
(0.478)\end{array}$ & $\begin{array}{c}9,207 \\
(5,555)\end{array}$ & $\begin{array}{l}11,138 \\
(4,674)\end{array}$ \\
\hline & PARSAVE & $\begin{array}{c}0.0107 \\
(0.0328)\end{array}$ & $\begin{array}{c}0.0125 \\
(0.0334)\end{array}$ & $\begin{array}{c}227 \\
(386)\end{array}$ & $\begin{array}{c}346 \\
(325)\end{array}$ \\
\hline $\begin{array}{l}\text { Observations } \\
\text { Log likelihood }\end{array}$ & & $\begin{array}{c}795 \\
-374.5\end{array}$ & $\begin{array}{c}795 \\
-358.1\end{array}$ & $\begin{array}{c}722 \\
-\end{array}$ & $\begin{array}{c}722 \\
-\end{array}$ \\
\hline
\end{tabular}


Table 10: Spouse's 401(k) Activity

\begin{tabular}{|c|c|c|c|c|c|}
\hline \multicolumn{2}{|c|}{ Variable } & \multirow{2}{*}{$\begin{array}{c}\begin{array}{c}\text { Equation (1) } \\
\text { Participation }\end{array} \\
\begin{array}{c}0.352 \\
(0.146)\end{array}\end{array}$} & \multirow{2}{*}{$\begin{array}{l}\text { Equation (2) } \\
\text { Participation }\end{array}$} & \multirow{2}{*}{$\begin{array}{c}\begin{array}{c}\text { Equation (3) } \\
\text { Balances }\end{array} \\
420 \\
(1,085)\end{array}$} & \multirow{2}{*}{$\begin{array}{c}\text { Equation (4) } \\
\text { Balances }\end{array}$} \\
\hline Education & OEBRE & & & & \\
\hline & UEBRE & & $\begin{array}{c}0.308 \\
(0.145)\end{array}$ & & $\begin{array}{l}1,205 \\
(839)\end{array}$ \\
\hline \multirow[t]{3}{*}{ Pensions } & SOPEN & $\begin{array}{l}-0.0769 \\
(0.151)\end{array}$ & $\begin{array}{c}-0.104 \\
(0.150)\end{array}$ & $\begin{array}{l}-3,682 \\
(1,184)\end{array}$ & $\begin{array}{l}-3,448 \\
(921)\end{array}$ \\
\hline & RE401K & $\begin{array}{c}0.185 \\
(0.150)\end{array}$ & $\begin{array}{c}0.218 \\
(0.147)\end{array}$ & $\begin{array}{c}987 \\
(1,136)\end{array}$ & $\begin{array}{c}556 \\
(885)\end{array}$ \\
\hline & ROPEN & $\begin{array}{l}-0.133 \\
(0.166)\end{array}$ & $\begin{array}{l}-0.113 \\
(0.165)\end{array}$ & $\begin{array}{c}85 \\
(1,231)\end{array}$ & $\begin{array}{c}317 \\
(960)\end{array}$ \\
\hline \multirow[t]{6}{*}{ Demographics } & FEMALE & $\begin{array}{c}-0.0494 \\
(0.162)\end{array}$ & $\begin{array}{c}-0.0234 \\
(0.161)\end{array}$ & $\begin{array}{c}-2,364 \\
(1,179)\end{array}$ & $\begin{array}{l}-2,700 \\
(925)\end{array}$ \\
\hline & BLACK & $\begin{array}{l}-0.164 \\
(0.293)\end{array}$ & $\begin{array}{l}-0.126 \\
(0.292)\end{array}$ & $\begin{array}{l}-2,218 \\
(2,376)\end{array}$ & $\begin{array}{c}-1,286 \\
(1,869)\end{array}$ \\
\hline & OTHER & $\begin{array}{c}0.279 \\
(0.336)\end{array}$ & $\begin{array}{c}0.270 \\
(0.335)\end{array}$ & $\begin{array}{c}3,763 \\
(2,310)\end{array}$ & $\begin{array}{c}3,401 \\
(1,818)\end{array}$ \\
\hline & SED & 0.114 & 0.121 & 786 & 782 \\
\hline & - & $(0.0460)$ & $(0.0458)$ & (342) & (269) \\
\hline & SAGE & $\begin{array}{l}0.00218 \\
(0.0109)\end{array}$ & $\begin{array}{l}0.00267 \\
(0.0109)\end{array}$ & $\begin{array}{l}194 \\
(77)\end{array}$ & $\begin{array}{l}206 \\
(61)\end{array}$ \\
\hline \multirow[t]{3}{*}{ Employment } & LSEARN & $\begin{array}{c}0.216 \\
(0.0845)\end{array}$ & $\begin{array}{c}0.222 \\
(0.0847)\end{array}$ & $\begin{array}{l}5,638 \\
(691)\end{array}$ & $\begin{array}{l}5,521 \\
(543)\end{array}$ \\
\hline & LREARN & $\begin{array}{c}0.0320 \\
(0.0218)\end{array}$ & $\begin{array}{c}0.0347 \\
(0.0216)\end{array}$ & $\begin{array}{l}-185 \\
(175)\end{array}$ & $\begin{array}{l}-160 \\
(139)\end{array}$ \\
\hline & SPART & $\begin{array}{l}-0.503 \\
(0.271)\end{array}$ & $\begin{array}{c}-0.460 \\
(0.270)\end{array}$ & $\begin{array}{c}1,998 \\
(2,120)\end{array}$ & $\begin{array}{c}1,267 \\
(1,637)\end{array}$ \\
\hline \multirow[t]{3}{*}{ Other } & Constant & $\begin{array}{c}-1.93 \\
(1.021)\end{array}$ & $\begin{array}{c}-2.09 \\
(1.021)\end{array}$ & $\begin{array}{l}-57,926 \\
(7,747)\end{array}$ & $\begin{array}{l}-56,974 \\
(6,090)\end{array}$ \\
\hline & TSCORE & $\begin{array}{l}-0.596 \\
(0.571)\end{array}$ & $\begin{array}{l}-0.531 \\
(0.570)\end{array}$ & $\begin{array}{l}-2,624 \\
(4,335)\end{array}$ & $\begin{array}{l}-3,262 \\
(3,382)\end{array}$ \\
\hline & PARSAVE & $\begin{array}{l}-0.0145 \\
(0.0397)\end{array}$ & $\begin{array}{l}-0.0143 \\
(0.0397)\end{array}$ & $\begin{array}{l}210 \\
(299)\end{array}$ & $\begin{array}{c}234 \\
(235)\end{array}$ \\
\hline $\begin{array}{l}\text { Observations } \\
\text { Log likelihood }\end{array}$ & & $\begin{array}{l}529 \\
-247.1\end{array}$ & $\begin{array}{c}529 \\
-247.8\end{array}$ & $\begin{array}{c}397 \\
-\end{array}$ & 397 \\
\hline
\end{tabular}


Table 11: Summary of Quantile Effects of Education on 401(k) Balances

\begin{tabular}{|c|c|c|c|}
\hline & & Efrect on Respondent's t01(k) Balance & Effect on Spouse's 401(k) Balance \\
\hline \multirow[t]{3}{*}{ OEBRE } & Basic median regression & $\begin{array}{c}2,508 \\
(1,435)\end{array}$ & $\begin{array}{c}420 \\
(1,085)\end{array}$ \\
\hline & 25 th percentile & $\begin{array}{l}1,113 \\
(590)\end{array}$ & $\begin{array}{l}1,022 \\
(555)\end{array}$ \\
\hline & 75th percentile & $\begin{array}{c}6,084 \\
(3,147)\end{array}$ & $\begin{array}{c}-466 \\
(2,947)\end{array}$ \\
\hline \multirow[t]{3}{*}{ UEBRE } & Basic median regression & $\begin{array}{c}2.826 \\
(1,058)\end{array}$ & $\begin{array}{l}1,205 \\
(839)\end{array}$ \\
\hline & 25 th percentile & $\begin{array}{l}2,161 \\
(502)\end{array}$ & $\begin{array}{l}1,069 \\
(444)\end{array}$ \\
\hline & 75th percentile & $\begin{array}{c}2.714 \\
(2.839)\end{array}$ & $\begin{array}{c}436 \\
(2,548)\end{array}$ \\
\hline
\end{tabular}

